Prepared in cooperation with the U.S. Army Corps of Engineers, Washington State Department of Ecology, and the Chehalis Basin Partnership

\title{
Hydrogeologic Framework and Groundwater/Surface-Water Interactions of the Chehalis River Basin, Southwestern Washington
}

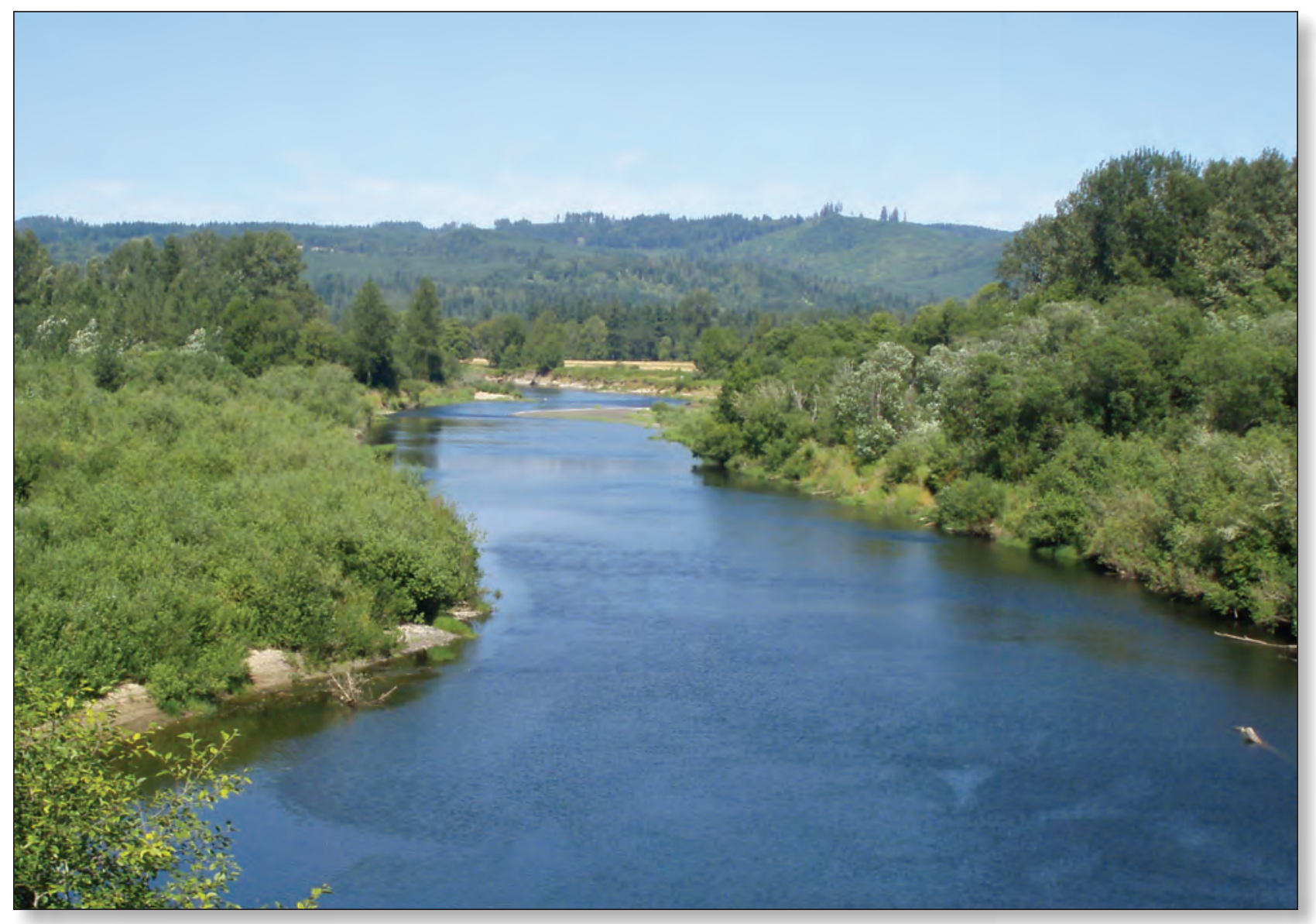

Scientific Investigations Report 2011-5160 
Cover: Photograph of the Chehalis River near Oakville, Washington.

(Photograph by Andrew Gendaszek, U.S. Geological Survey, July 27, 2010.) 


\section{Hydrogeologic Framework and Groundwater/ Surface-Water Interactions of the Chehalis River Basin, Southwestern Washington}

By Andrew S. Gendaszek

Prepared in cooperation with the U.S. Army Corps of Engineers,

Washington State Department of Ecology, and the Chehalis Basin Partnership

Scientific Investigations Report 2011-5160 


\title{
U.S. Department of the Interior \\ KEN SALAZAR, Secretary \\ U.S. Geological Survey \\ Marcia K. McNutt, Director
}

\author{
U.S. Geological Survey, Reston, Virginia: 2011
}

For more information on the USGS - the Federal source for science about the Earth, its natural and living resources, natural hazards, and the environment, visit http://www.usgs.gov or call 1-888-ASK-USGS.

For an overview of USGS information products, including maps, imagery, and publications, visit http://www.usgs.gov/pubprod

To order this and other USGS information products, visit http://store.usgs.gov

Any use of trade, product, or firm names is for descriptive purposes only and does not imply endorsement by the U.S. Government.

Although this report is in the public domain, permission must be secured from the individual copyright owners to reproduce any copyrighted materials contained within this report.

Suggested citation:

Gendaszek, A.S., 2011, Hydrogeologic framework and groundwater/surface-water interactions of the Chehalis River basin, Washington: U.S. Geological Survey Scientific Investigations Report 2011-5160, 42 p. 


\section{Contents}

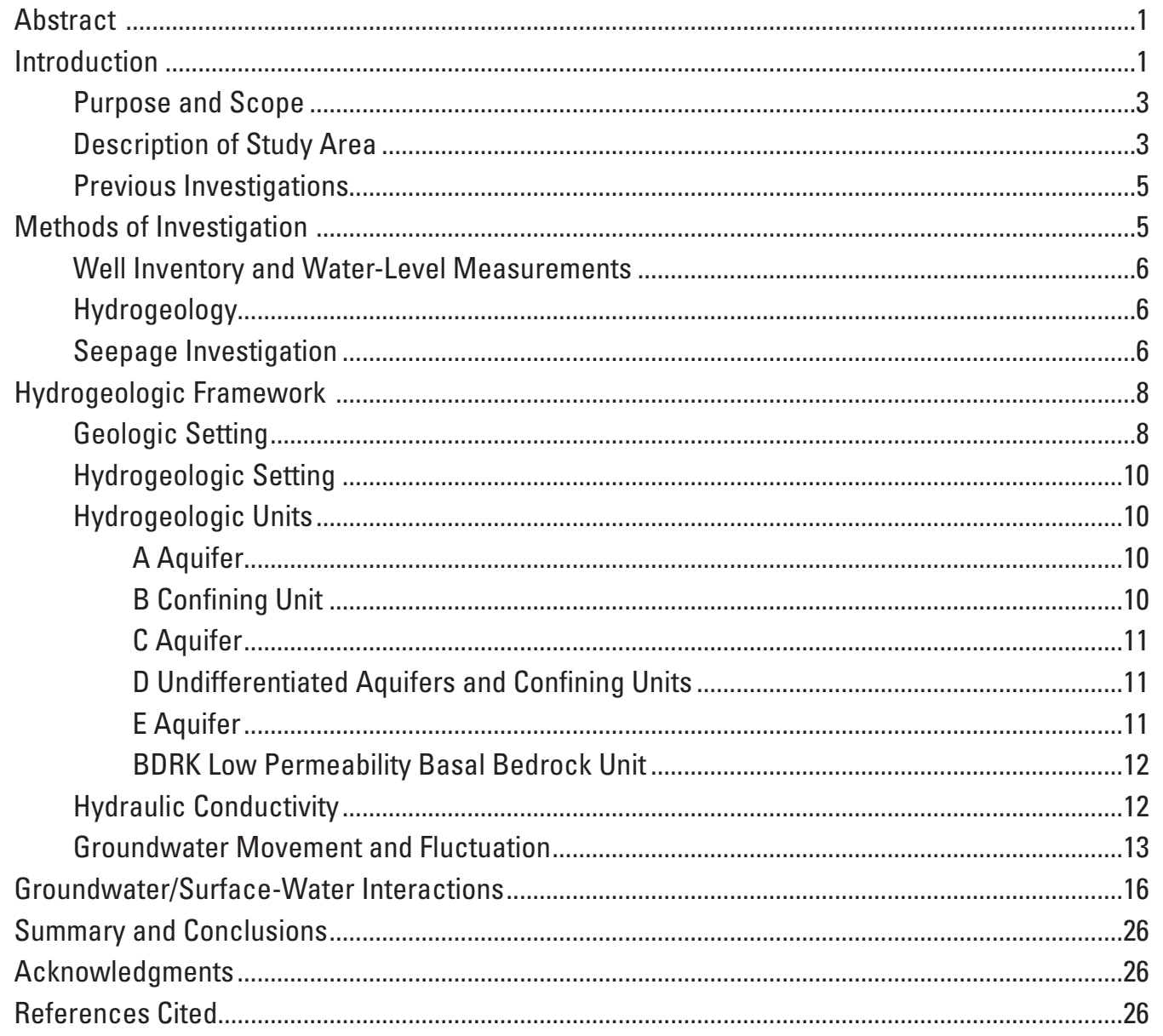

\section{Plate}

Plate 1. Map and hydrogeologic sections showing location of inventoried wells, surficial geology, and hydrogeologic units in the Chehalis River basin, Washington. 


\section{Figures}

Figure 1. Map showing location of the Chehalis River basin, southwestern Washington $\quad \ldots \quad 2$

Figure 2. Map showing mean annual precipitation in the Chehalis River basin, southwestern Washington, 1971-2000

Figure 3. Graph showing mean daily discharge at USGS streamflow-gaging station 12031000 on the Chehalis River at Porter, southwestern Washington, water years 1953-2009.

Figure 4. Graph showing discharge for two U.S. Geological Survey streamflow-gaging stations, Chehalis River basin, southwestern Washington, August 17-19, 2010 _. 7

Figure 5. Map showing extent of Puget Lobe of the Cordilleran Ice Sheet and location of Cascadia Subduction Zone in western Washington and Oregon

Figure 6. Map showing water-table altitudes and inferred direction of groundwater flow in the surficial aquifers, Chehalis River basin, southwestern Washington, August-September 2009

Figure 7. Graph showing water-level altitudes for nested wells $(A)$ 15N/03W-03A02P1 and 15N/03W-03A02P3, (B) 15N/03W-10D02P1 and 15N/03W-10D02P3, and (C) 16N/03W-33P01P1 and 16N/03W-33P01P3, Chehalis River basin, Washington, August 2009-0ctober 2010

Figure 8. Map showing streamflow gaining, losing, and near-neutral reaches, central Chehalis River Basin, southwestern Washington, August 2010

Figure 9. Graph showing cumulative river-aquifer exchanges for the central Chehalis River, southwestern Washington, August 2010 and September 2007

Figure 10. Graphs showing continuous water levels in wells, stream stage at U.S. Geological Survey streamflow-gaging station 12027500, Chehalis River at Grand Mound, and total monthly precipitation at Centralia, October 2009-September 2010 for wells 14N/02W-07B02 (A), 14N/02W-06C02 $(B), 15 \mathrm{~N} / 04 \mathrm{~W}-02 \mathrm{~N} 03(C), 15 \mathrm{~N} / 04 \mathrm{~W}-03 \mathrm{R} 02(D), 15 \mathrm{~N} / 03 \mathrm{~W}-08 \mathrm{~B} 01(E)$, and 15N/03W-03A02P3 $(F)$, Chehalis River basin, southwestern Washington

Figure 11. Graph showing water levels in well 17N/07W-08K02 and stream stage at U.S. Geological Survey streamflow-gaging station 12035100, Chehalis River at Montesano, April 1, 2010-April 11, 2010, Chehalis River basin, southwestern Washington

\section{Tables}

Table 1. Hydrogeologic units in the Chehalis River basin, southwestern Washington 11

Table 2. Estimates of hydraulic conductivity in the Chehalis River basin, southwestern Washington

Table 3. Evaluation of gains and losses, with error analysis measurements for the seepage investigation, central Chehalis River Basin, southwestern Washington, August 2010

Table 4. Evaluation of gains and losses, with error analysis measurements for the seepage investigation tributaries of central Chehalis River, southwestern Washington, August 2010

Table 5. Select physical and hydrologic data for the project wells in the Chehalis River basin, southwestern Washington 


\section{Conversion Factors and Datums}

Inch/Pound to SI

\begin{tabular}{|c|c|c|}
\hline Multiply & By & To obtain \\
\hline \multicolumn{3}{|c|}{ Length } \\
\hline foot (ft) & 0.3048 & meter (m) \\
\hline mile (mi) & 1.609 & kilometer $(\mathrm{km})$ \\
\hline \multicolumn{3}{|c|}{ Area } \\
\hline square mile (mi2) & 2.590 & square kilometer $\left(\mathrm{km}^{2}\right)$ \\
\hline \multicolumn{3}{|c|}{ Flow Rate } \\
\hline cubic foot per day $\left(\mathrm{ft}^{3} / \mathrm{d}\right)$ & 0.02832 & cubic meter per day $\left(\mathrm{m}^{3} / \mathrm{d}\right)$ \\
\hline cubic foot per second $\left(\mathrm{ft}^{3} / \mathrm{s}\right)$ & 0.02832 & cubic meter per second $\left(\mathrm{m}^{3} / \mathrm{s}\right)$ \\
\hline $\begin{array}{l}\text { cubic foot per second per square } \\
\text { mile }\left[\left(\mathrm{ft}^{3} / \mathrm{s}\right) / \mathrm{mi}^{2}\right]\end{array}$ & 0.01093 & $\begin{array}{l}\text { cubic meter per second per square } \\
\text { kilometer }\left[\left(\mathrm{m}^{3} / \mathrm{s}\right) / \mathrm{km}^{2}\right]\end{array}$ \\
\hline cubic foot per mile $\left(\mathrm{ft}^{3} / \mathrm{mi}\right)$ & 0.01760 & cubic meters per kilometer $\left(\mathrm{m}^{3} / \mathrm{km}\right)$ \\
\hline inches per year (in/yr) & 2.54 & centimeters per year (cm/yr) \\
\hline foot per day (ft/d) & 0.3048 & meter per day $(\mathrm{m} / \mathrm{d})$ \\
\hline foot per mile $(\mathrm{ft} / \mathrm{mi})$ & 0.1894 & meter per kilometer $(\mathrm{m} / \mathrm{km})$ \\
\hline
\end{tabular}

Temperature in degrees Celsius $\left({ }^{\circ} \mathrm{C}\right)$ may be converted to degrees Fahrenheit $\left({ }^{\circ} \mathrm{F}\right)$ as follows:

$$
{ }^{\circ} \mathrm{F}=\left(1.8 \mathrm{x}^{\circ} \mathrm{C}\right)+32 .
$$

Temperature in degrees Fahrenheit $\left({ }^{\circ} \mathrm{F}\right)$ may be converted to degrees Celsius $\left({ }^{\circ} \mathrm{C}\right)$ as follows:

$$
{ }^{\circ} \mathrm{C}=\left({ }^{\circ} \mathrm{F}-32\right) / 1.8 \text {. }
$$

Datums

Vertical coordinate information is referenced to the insert datum name (and abbreviation) here for instance, "North American Vertical Datum of 1988 (NAVD 88)."

Horizontal coordinate information is referenced to the insert datum name (and abbreviation) here for instance, "North American Datum of 1983 (NAD 83)."

Altitude, as used in this report, refers to distance above the vertical datum.

*Transmissivity: The standard unit for transmissivity is cubic foot per day per square foot times foot of aquifer thickness $\left[\left(\mathrm{ft}^{3} / \mathrm{d}\right) / \mathrm{ft}^{2}\right] \mathrm{ft}$. In this report, the mathematically reduced form, foot squared per day $\left(\mathrm{ft}^{2} / \mathrm{d}\right)$, is used for convenience.

\section{Abbreviations and Acronyms}

$\begin{array}{ll}\text { ADCP } & \text { Acoustic Doppler Current Profiler } \\ \text { BDRK } & \text { Bedrock Low Permeability Unit } \\ \text { CBP } & \text { Chehalis Basin Partnership } \\ \text { Kya } & \text { Thousand Years Ago } \\ \text { NWIS } & \text { National Water Information System } \\ \text { USGS } & \text { U.S. Geological Survey } \\ \text { WADOE } & \text { Washington State Department of Ecology }\end{array}$




\section{Well-Numbering System}

In Washington, wells are assigned numbers that identify their location within a township, range, section, and 40-acre tract. Number 15N/02W-12A01 indicates that the well is in Township 15 North and Range 02 West, north and west of the Willamette Base Line and Meridian, respectively. The numbers immediately following the hyphen indicate the section (12) within the township; the letter following the section gives the 40-acre tract of the section, as shown on figure 4 . The two-digit sequence number (01) following the letter indicates that the well was the first one inventoried by project personnel in that 40 -acre tract. A " $\mathrm{D}$ " following the sequence number indicates that the well has been deepened. In the illustrations of this report, wells are identified individually by only the section and 40 -acre tract, such as 12A01; township and range are shown on the map borders.

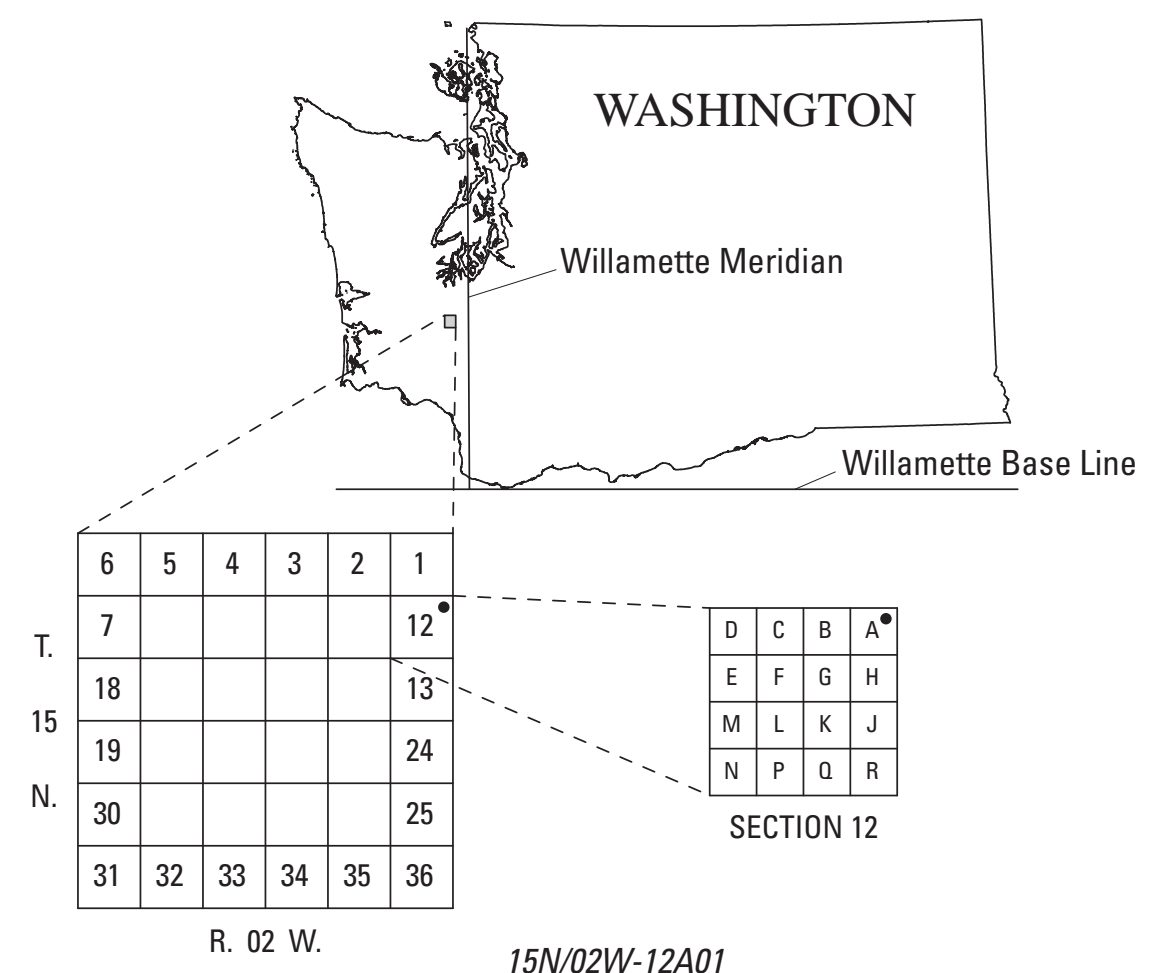




\title{
Hydrogeologic Framework and Groundwater/ Surface-Water Interactions of the Chehalis River Basin, Southwestern Washington
}

\author{
By Andrew S. Gendaszek
}

\section{Abstract}

The Chehalis River has the largest drainage basin of any river entirely contained within the State of Washington with a watershed of approximately 2,700 $\mathrm{mi}^{2}$ and has correspondingly diverse geology and land use. Demands for water resources have prompted the local citizens and governments of the Chehalis River basin to coordinate with Federal, State and Tribal agencies through the Chehalis Basin Partnership to develop a long-term watershed management plan. The recognition of the interdependence of groundwater and surface-water resources of the Chehalis River basin became the impetus for this study, the purpose of which is to describe the hydrogeologic framework and groundwater/ surface-water interactions of the Chehalis River basin.

Surficial geologic maps and 372 drillers' lithostratigraphic logs were used to generalize the basin-wide hydrogeologic framework. Five hydrogeologic units that include aquifers within unconsolidated glacial and alluvial sediments separated by discontinuous confining units were identified. These five units are bounded by a low permeability unit comprised of Tertiary bedrock.

A water table map, and generalized groundwater-flow directions in the surficial aquifers, were delineated from water levels measured in wells between July and September 2009. Groundwater generally follows landsurface-topography from the uplands to the alluvial valley of the Chehalis River. Groundwater gradients are highest in tributary valleys such as the Newaukum River valley (approximately 23 cubic feet per mile), relatively flat in the central Chehalis River valley (approximately 6 cubic feet per mile), and become tidally influenced near the outlet of the Chehalis River to Grays Harbor.

The dynamic interaction between groundwater and surface-water was observed through the synoptic streamflow measurements, termed a seepage run, made during August 2010, and monitoring of water levels in wells during the 2010 Water Year. The seepage run revealed an overall gain of $56.8 \pm 23.7$ cubic feet per second over 32.8 river miles (1.7 cubic feet per second per mile), and alternating gains and losses of streamflow ranging from -48.3 to 30.9 cubic feet per second per mile, which became more pronounced on the Chehalis River downstream of Grand Mound. However, most gains and losses were within measurement error. Groundwater levels measured in wells in unconsolidated sediments fluctuated with changes in stream stage, often within several hours. These fluctuations were set by precipitation events in the upper Chehalis River basin and tides of the Pacific Ocean in the lower Chehalis River basin.

\section{Introduction}

The Chehalis River flows about $125 \mathrm{mi}$ from its headwaters in the Willipa Hills through forestland, agricultural lands, the cities of Chehalis and Centralia, and the Confederated Tribes of the Chehalis Reservation to its outlet at Grays Harbor (fig. 1). Most development and water use within the Chehalis River basin is within the valleys of the Chehalis River and its major tributaries. Wells located within the major river valleys generally are completed within aquifers in the unconsolidated glacial and alluvial sediments and do not penetrate bedrock comprised of basalt and sedimentary rock.

The groundwater and surface-water systems of the Chehalis River basin supply residential, agricultural, and industrial users with water while sustaining instream and riparian ecosystems. These complex systems are connected in the Chehalis River basin (Sinclair and Hirschey, 1992; Pitz and others, 2005; Ely and others, 2008) and may not be fully understood independently of each other. Low summer streamflows and coincident high water temperatures impact the migration of anadromous fish on the Chehalis River and its tributaries, while seasonally low water levels in rivers and wells impact water availability for human use. Future water availability, particularly during the summer low-flow period, has prompted concern among the citizens and governments of the Chehalis River basin, as population growth increases the demand for water resources. Characterization of the shallow groundwater system and its interaction with the surface-water system is therefore necessary to plan for current and future water needs in the Chehalis River basin. 

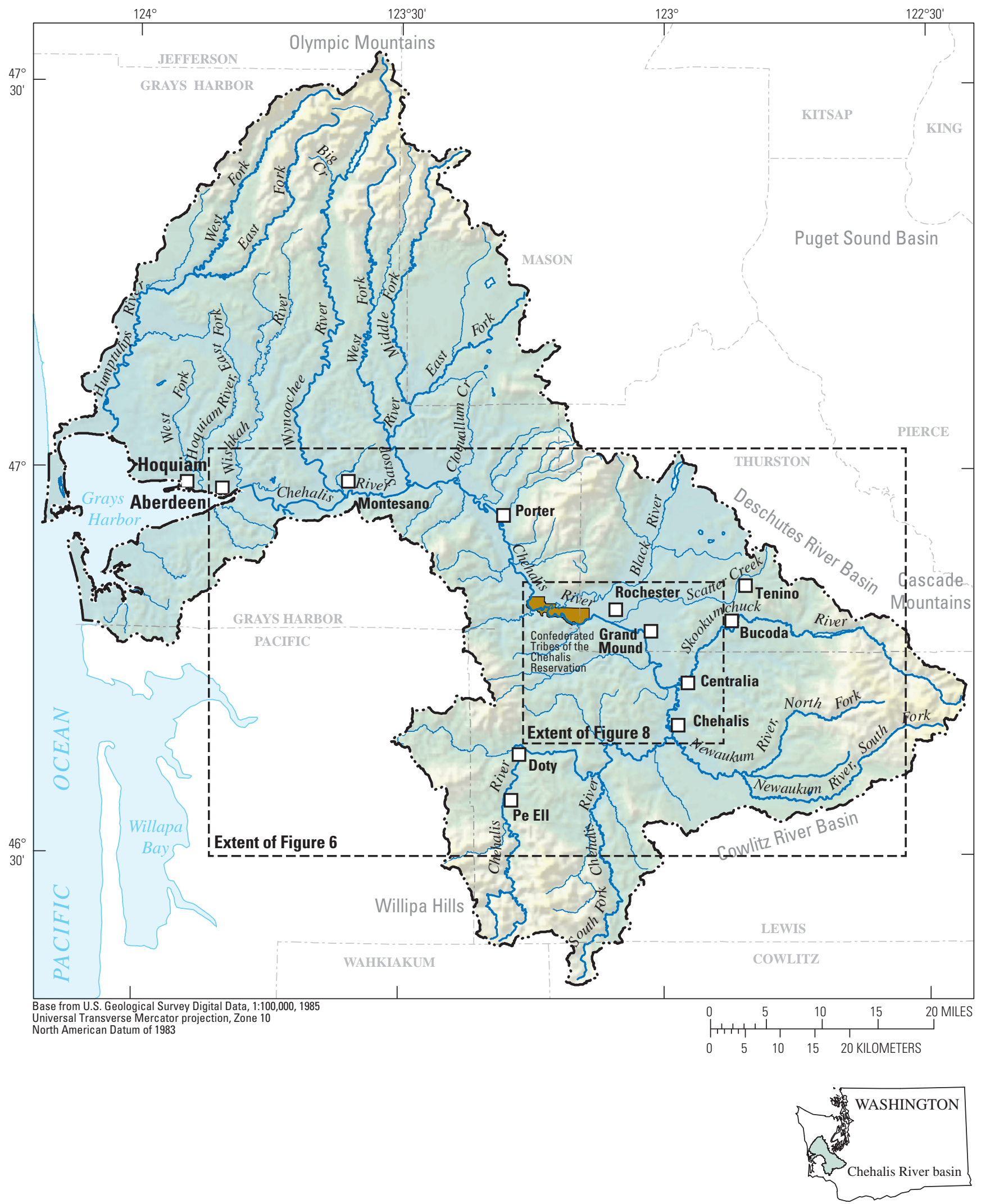

Figure 1. Location of the Chehalis River basin, southwestern Washington. 
The Chehalis Basin Partnership (CBP), created by local citizens and governments, together with State and Tribal agencies acting under the guidelines of the Watershed Management Act of 1998 (Washington State Engrossed Substitute House Bill 2514), is working to implement a sustainable watershed plan that considers the groundwater and surface-water systems together, to address concerns about water quantity and quality, in-stream flows, and fish habitat.

Parts of the groundwater-flow system of the Chehalis River basin have been previously described (for example, Sinclair and Hirschey, 1992; Drost and others, 1998; Pitz and others, 2005), but a comprehensive, basin-wide assessment of the groundwater resources in the Chehalis River basin had not been done prior to this report. The basinwide hydrogeologic framework presented in this report was described in the context of generalized (Ely and others, 2008) and spatially refined information about groundwater/surface-water interactions presented in this report. This information will allow the CBP to more effectively plan and manage the water resources of the Chehalis River basin for use by humans, fish, and wildlife as population and development increases.

\section{Purpose and Scope}

The purpose of this report is to describe the generalized hydrogeologic framework of the Chehalis River basin, and to characterize the interactions between the groundwater-flow system and the Chehalis River and its major tributaries. The hydrogeologic framework presented in this report builds upon previously described hydrogeologic frameworks of parts of the Chehalis River basin (Sinclair and Hirschey, 1992; Drost and others, 1998; Pitz and others, 2005). This report includes an overview of the geologic history of the Chehalis River basin, a characterization of significant hydrogeologic units, groundwater levels, and generalized flow directions within significant aquifers. Streamflow gains and losses at selected intervals along the Chehalis River and its selected tributaries also are presented to describe groundwater/surface-water interactions in the Chehalis River basin.

\section{Description of Study Area}

The Chehalis River basin encompasses approximately 2,700 $\mathrm{mi}^{2}$ in southwestern Washington. The basin is bounded to the north by the Olympic Mountains and a low divide with the Puget Sound basin, to the east by the Cascade Mountains, to the south by the Willipa Hills, and to the west by the Pacific Ocean (ig. 1). Altitudes of the Chehalis River basin range from approximately 5,000 ft at Capitol Peak in the Olympic Mountains to sea level at the outlet of the Chehalis River at Grays Harbor. The Chehalis River basin is predominantly forested (74 percent) with some developed land (7 percent, primarily in the Chehalis-Centralia and Aberdeen-Hoquiam areas), wetlands (6 percent), agricultural lands (5 percent; Homer and others, 2004) in the main river valleys, and other land types (8 percent). The Chehalis River basin includes parts of Lewis, Pacific, Thurston, Mason, Grays Harbor, Cowlitz, and Jefferson Counties, and the entire Confederated Tribes of the Chehalis Reservation.

The temperate marine climate of the Chehalis River basin is characterized by cool, wet winters and warm, dry summers. Mean annual (1971-2000) precipitation ranges from more than 250 in. in the headwaters of the Wynoochee and Humptulips Rivers to 43 in. near the cities of Chehalis and Centralia (PRISM Group, 2011) (fig. 2). About 75 percent of the precipitation measured between 1971 and 2000 at the Centralia weather station, altitude $185 \mathrm{ft}$, fell between October and March (National Oceanic and Atmospheric Administration, 2010). Mean annual discharge at the downstream-most gaging station upstream of the tidal influence of Grays Harbor (Chehalis River at Porter, Washington: 12031000) for 1953-2009 was 4,049 $\mathrm{ft}^{3} / \mathrm{s}$. At this station for 1953-2009, mean monthly discharge was lowest in August (414 ft $3 / \mathrm{s}$ ) and highest in January (9,520 ft $3 / \mathrm{s}$ ) (fig. 3 ).

Three main types of rocks and sediments are exposed within the Chehalis River basin, including Tertiary sedimentary and volcanic rocks, Pleistocene glacial drift, andrecent alluvium (Snavely and others, 1958). Uplifted Tertiary marine and non-marine sedimentary rocks deposited on the western margin of North America comprise the bedrock foundation of the Chehalis River basin. Glacial drift from both alpine glaciers originating from the Cascade and Olympic Mountains and the Puget Lobe of the Cordilleran Ice Sheet were deposited in the Chehalis River basin at least twice during the Pleistocene. Recent alluvium overlies much of the Pleistocene glacial deposits within the valleys of the Chehalis River and its major tributaries. Significant groundwater resources within the Chehalis River basin are contained within the well-sorted sands and gravels of the unconsolidated deposits that were deposited by outwash streams and modern rivers (Wallace and Molenaar, 1961; Weigle and Foxworthy, 1962; Eddy, 1966; Noble and Wallace, 1966). 


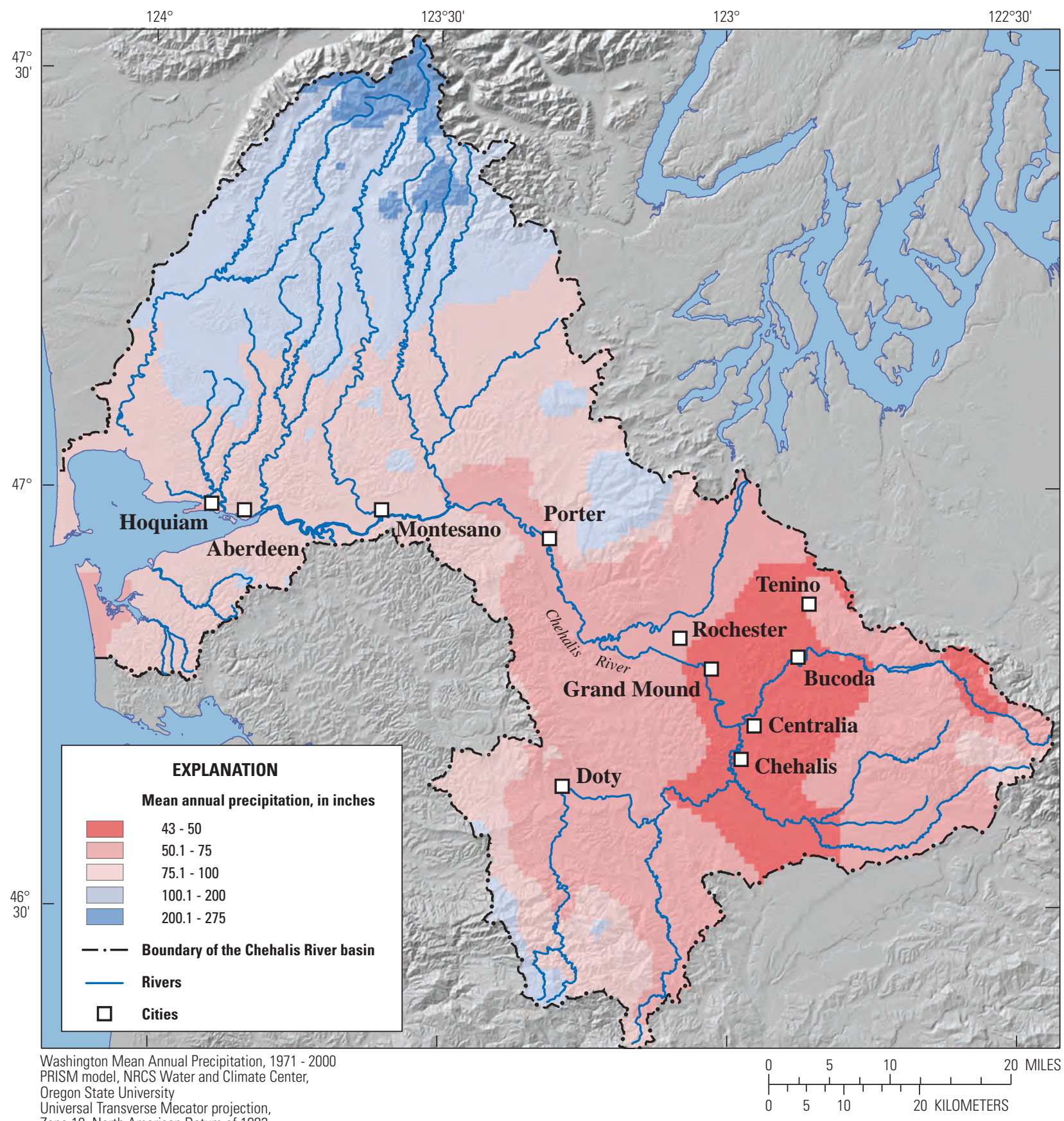

Universal Transverse Mecator projection,
Zone 10, North American Datum of 1983

Figure 2. Mean annual precipitation in the Chehalis River basin, southwestern Washington, 1971-2000. 


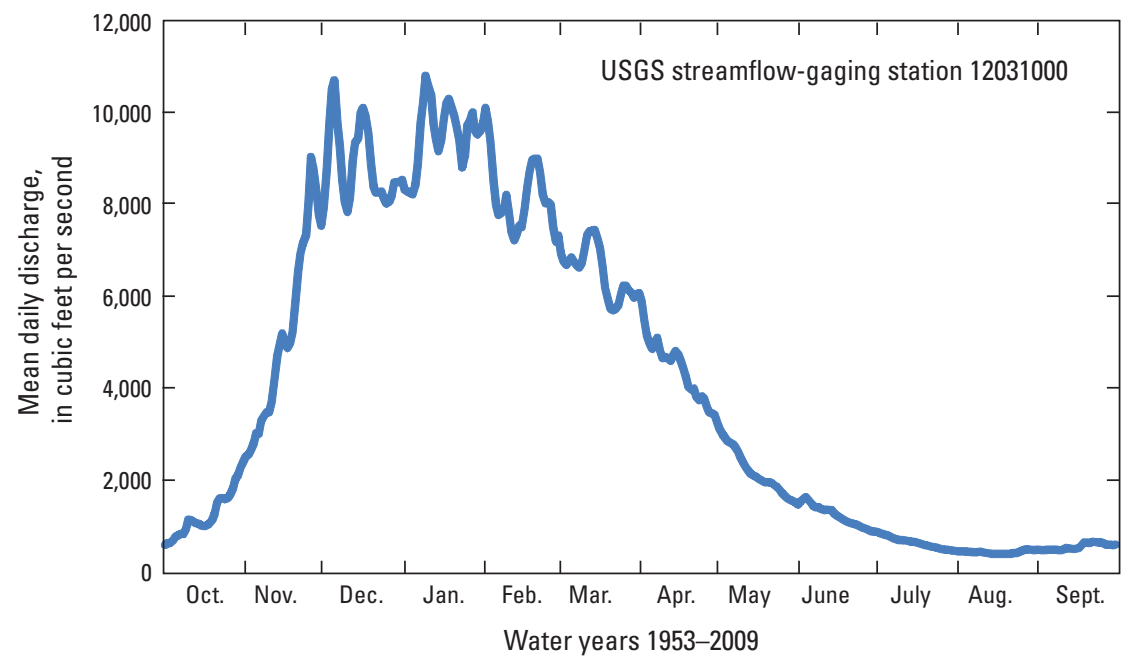

Figure 3. Mean daily discharge at USGS streamflow-gaging station 12031000 on the Chehalis River at Porter, southwestern Washington, water years 1953-2009.

\section{Previous Investigations}

This investigation builds upon several previous studies of the hydrogeology of the Chehalis River basin, which varied in scope and purpose. The earliest studies published as Water Supply Bulletins by the State of Washington (Wallace and Molenaar, 1961; Weigle and Foxworthy, 1962; Eddy, 1966; Noble and Wallace, 1966) described regional hydrogeologic units and the occurrence and quality of groundwater. Several more recent studies built upon this work in the Scatter Creek and Black River area (Sinclair and Hirschey, 1992), northern Thurston County (Drost and others, 1998), and the Chehalis-Centralia area (Pitz and others, 2005). A regional characterization of surficial aquifers was also completed by Garrigues and others (1998). The hydrogeologic framework presented in this report generalizes the hydrogeologic characterizations presented in these previous investigations into a regional framework and considers more recent geologic mapping (Logan and others, 2009) and well-log information.

\section{Methods of Investigation}

Basic hydrologic and geologic data, including a field inventory of wells, measurement of water levels in wells, and extents of surficial geologic units were collected to delineate hydrogeologic unit maps, hydrogeologic crosssections, and water-level maps. Several existing wells near the Chehalis River and its major tributaries were monitored at monthly intervals and some were instrumented with pressure transducers for comparison to stream stage measured at streamflow-gaging stations in order to determine the dynamics of groundwater/surface-water interaction during water year 2010. Streamflow was measured during a 3-day period at 41 locations along the Chehalis River and its tributaries to determine bulk streamflow gains and losses during summer low-flow conditions. 


\section{Well Inventory and Water-Level Measurements}

A field inventory of 360 wells was completed between July and September 2009 to acquire information about the spatial distribution of the physical and hydraulic properties of the geologic units that comprise the groundwater-flow system of the Chehalis River basin (table 5, at back of report; Fasser and Julich, 2010). In addition, 12 wells from previous USGS studies were used to augment information provided by wells inventoried in 2009 for the construction of hydrogeologic cross-sections. The location of each well was surveyed using a Global Positioning System receiver with a horizontal accuracy of $\pm 10 \mathrm{ft}$. The altitude of the land surface at each well location was interpolated from a U.S. Geological Survey (USGS) Digital Elevation Model with a 1/3 arc-second cell spacing and a vertical accuracy of $\pm 8 \mathrm{ft}$. Well logs obtained from the Washington State Department of Ecology (WADOE) or well owners were linked with field inventory wells through WADOE unique well identification tags. Well-construction details including depth, screened interval, and lithologic units encountered were determined from drillers' well logs. Depth to water was recorded at most wells in accordance with standard USGS techniques (Drost, 2005) using a calibrated electric tape or graduated steel tape, both with accuracies of $0.01 \mathrm{ft}$. All well inventory data-including well location, construction, and water-level measurements-were entered into the USGS National Water Information System (NWIS) database.

A subset of 14 of the 360 inventoried wells located in the surficial aquifers near the Chehalis River were monitored at monthly intervals from November 2009 to October 2010 and entered into the NWIS database. Hourly waterlevel measurements were recorded at six wells within the monthly monitoring network by pressure transducers (In-Situ Level Troll 500). Wells within the monthly and hourly monitoring networks were selected to evaluate groundwater/ surface-water interactions, and to document seasonal fluctuations in groundwater levels in surficial aquifers away from major withdrawal areas (table 5).

\section{Hydrogeology}

Surficial geology of the Chehalis River basin was simplified from existing surficial geologic maps including the 1:100,000 scale geologic maps of the Centralia quadrangle (Schasse, 1987), the Chehalis River and Westport quadrangles (Logan, 1987), and the Shelton quadrangle (Logan, 2003). These maps were compiled into a digital map database by the Washington State Division of Geology and Earth Resources (2005). Recent 1:24,000 geologic mapping by Logan and others (2009) provided additional details of the Maytown Quadrangle in southern Thurston County. Modifications to the extent of existing mapped units were made in some areas based on lithologic information from drillers' lithostratigraphic logs obtained during this study.

\section{Seepage Investigation}

Forty-one discharge measurements were made during low-flow season to capture baseflow conditions over a 3-day period in August 2010 along the Chehalis, Skookumchuck, and Black Rivers, Scatter Creek, and select smaller tributaries (U.S. Geological Survey, 2011). The net volume of water exchanged between the surface-water and groundwater systems over the stream length between discharge measurement sites - termed the seepage reach—was calculated as the increase or decrease in streamflow that is not accounted for by tributary inflows or diversions between the two discharge measurement sites. Calculated streamflow gains and losses are expressed as the net volume of water exchanged over the seepage reach in cubic feet per second, and the net volume of water exchanged normalized by the seepage reach length in cubic feet per second per mile.

Most discharge measurements used to calculate groundwater/surface-water exchanges were measured on the same day, but some measurements were made up to 2 days apart, introducing uncertainty of the same magnitude as measurement error into the groundwater/surface-water exchange estimates. Mean daily discharge varied by $19 \mathrm{ft}^{3} / \mathrm{s}$, or 8 percent of mean daily streamflow $\left(237 \mathrm{ft}^{3} / \mathrm{s}\right)$ during the seepage investigation, at the Chehalis River near Grand Mound (USGS gage 12027500), and by $18 \mathrm{ft} 3 / \mathrm{s}$, or 4 percent of mean daily discharge (449 $\left.\mathrm{ft}^{3} / \mathrm{s}\right)$, during the seepage investigation at the Chehalis River at Porter (USGS gage 12031000) (fig. 4). 


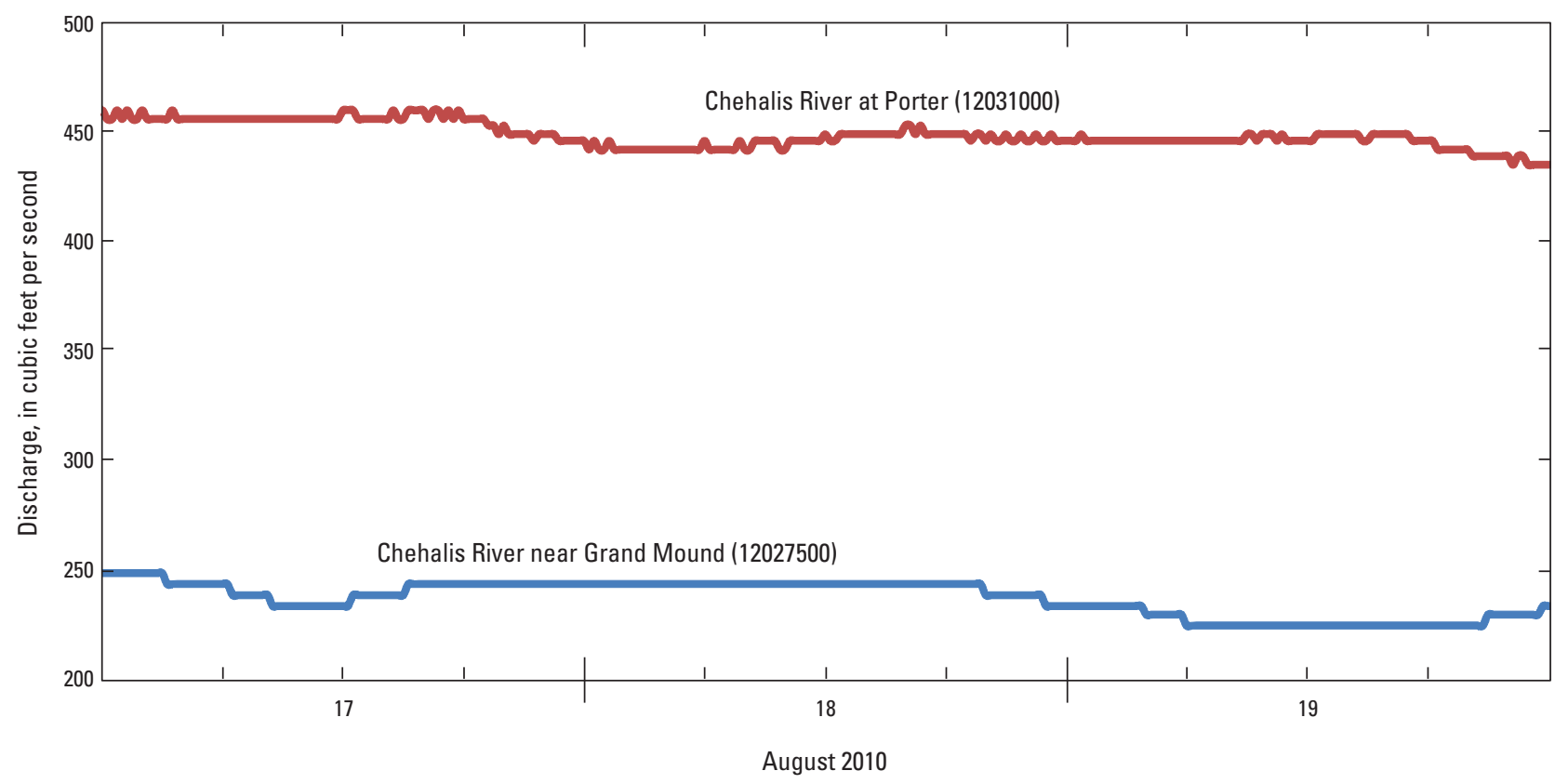

Figure 4. Discharge for two U.S. Geological Survey streamflow-gaging stations, Chehalis River basin, southwestern Washington, August 17-19, 2010.

Discharge was measured using the velocity-area method using standardized USGS techniques with a Price AA meter (Rantz, 1982) or an acoustic Doppler current profiler (ADCP; Oberg and others, 2005). Measurement sites inaccessible by vehicle were measured by a two-person team using a kayakmounted ADCP to traverse the river, allowing for an increased density of seepage measurements in this study. Each discharge measurement was assigned an accuracy rating of "good," indicating measurements are within 5 percent margin of error; "fair," indicating measurements are within 8 percent margin of error; and "poor," indicating that measurements have an error of 8 percent or more (Sauer and Meyer, 1992). The measurement error associated with the upstream, downstream, tributary, and diversion streamflow measurements used to calculate a single seepage gain or loss was propagated using the following formula for each seepage reach (Wheeler and Eddy-Miller, 2005):

$$
s=\sqrt{( \pm a)^{2}+( \pm b)^{2}+\ldots( \pm n)^{2}},
$$

where

$s$ is the prorogated error of the individual of the $a, b, \ldots, n$ discharge measurements associated with seepage gain or loss calculation.

Many small surface-water diversions and returns of up to 4.2 and $5.7 \mathrm{ft}^{3} / \mathrm{s}$, respectively, occur within the Chehalis River and its tributaries, but their quantification was outside the scope of this study. These unmeasured diversions and returns are most active during the summer irrigation season and introduce some error into the calculated streamflow gains and losses. 


\section{Hydrogeologic Framework}

\section{Geologic Setting}

The Chehalis River basin occupies the southern margin of the Puget Lowland, a glacially modified structural basin, and extends into the foothills of the Cascade Mountains, and the Willipa Hills and Olympic Mountains of the Washington Coast Ranges. Tectonic and glacial processes during the Tertiary and Quaternary periods have shaped the present topography, stratigraphy, and structure of the Chehalis River basin (fig. 5).

Tertiary to present convergence of the North American continental plate and the Farrallon and Juan de Fuca oceanic plates has resulted in the formation and maintenance of a subduction zone and volcanic arc along the western margin of the North American plate (Wells and others, 1984). Marine sediments and several exotic terranes were scraped off the leading edge of the subducting oceanic plates prograding the margin of North America westward. The Tertiary volcanic, as well as the marine and non-marine sedimentary, rocks deposited along this margin were uplifted to their present position as a result of this convergence resulting in dominant southeast-northwest trending faults and folds (Snavely and others, 1958). The Juan de Fuca Plate is currently converging at a rate of 1-1.5 in/yr obliquely towards the North American Plate (Heaton and Kanamori, 1984).

During the Pleistocene Epoch of the Quaternary Period, the Puget Lobe of the Cordilleran Ice Sheet advanced into the northwestern portion of the Chehalis River basin at least twice (Bretz, 1913; Lea, 1984), most recently about 15,000 years ago (15 Kya) during the Vashon Stade (glacial readvance) of the Fraser Glaciation. The pre-existing bedrock topography surrounding the Puget Lowland including the Olympic and Cascade Mountains determined both the extent of the Puget Lobe and its meltwater drainage. After the advance of the Puget Lobe southward of the Strait of Juan de Fuca, large proglacial lakes formed in the Puget Lowland, eventually draining through an outlet at the southern terminus of the Puget Lowland through the modern Chehalis River valley and depositing thick sequences of advance glacial outwash. The Puget Lobe during Vashon time reached its maximum extent ca. 13.5 Kya, forming terminal moraines north of Rochester and depositing till farther to the north. During deglaciation, meltwater was routed through a series of spillways and valleys (Logan and others, 2009), dissecting the Vashon terminal moraine and depositing recessional glacial outwash within the Chehalis River valley and the valleys of several of its tributaries, primarily Scatter Creek and the Skookumchuck, Black, and Satsop Rivers. Coarse-grained recessional outwash was deposited as far south as Centralia, damming the Chehalis River valley and its tributaries upstream of this point to form glacial Lake Chehalis (Bretz, 1913) where fine-grained lacustrine sediments were deposited. The Puget Lobe occupied the Chehalis River basin at least once before during the Fraser Glaciation, but extended 1-7 mi beyond its Vashon extent more than $125 \mathrm{Kya}$, depositing a drift sequence termed the Penultimate drift by Lea (1984) as far south as Centralia. Unlike Vashon-age drift, which crops out widely in the northern Chehalis River basin, the Penultimate drift has limited surface exposure and its original topographic form is less well-preserved because it has been eroded or covered by Vashon-age drift.

Alpine glaciers originating in the Olympic and Cascade Mountains also advanced several times during the Pleistocene into the Chehalis River basin, depositing several sequences of the drift in headwaters and valleys. The Logan Hill drift was deposited as an outwash plain or valley train unconformably on Tertiary rocks by alpine glaciers originating from the Cascades and consists of Cascade-derived volcanic and sedimentary rocks of Tertiary age (Snavely and others, 1958) prior to the development of the modern volcanic cone of Mt. Rainier (Easterbrook, 1986). No radiometric dates or paleomagnetic data exist, but Crandell (1963) correlates the Logan Hill drift with the Orting Drift deposited by the Puget Lobe of the Cordilleran ice sheet during the Early Pleistocene. Most of the Logan Hill drift consists of sand and gravel outwash, but isolated layers of till also exist (Crandell and Miller, 1974). Subsequent erosion has reduced the extent of the Logan Hill drift to the bedrock uplands, and the upper 24-74 ft has been intensely weathered to clay (Snavely and others, 1958). Outwash from two additional advances of Cascade alpine glaciers was deposited during the Middle Pleistocene as the Hayden Creek and Wingate Hill drifts, although the glaciers terminated outside of the modern Chehalis River basin (Crandell and Miller, 1974). The Wingate Hill and Hayden Creek drifts are much less areally extensive than the Logan Hill drift and are confined to terraces bordering Newaukum and Chehalis River valleys.

Alpine glaciers have advanced from the Olympic Mountains at least four times during the Pleistocene (Logan, 2003 and references therein), depositing across the northwestern portion of the Chehalis River basin till and outwash composed of marine sedimentary and volcanic rocks derived from the interior of the Olympic Mountains. Logan (2003) correlated locally named drift sequences of previous workers across the southern Olympic Mountains, grouping them into drift from four Pleistocene glacial advances: two during Wisconsinan time, and two prior to Wisconsinan time. Although the relative chronology of Olympic Mountain alpine glacial advances has been studied considerably, the absolute chronology remains relatively unknown except for alpine glacial advances farther to the north in the Hoh River and Queets River basins (Thackray, 1996). 


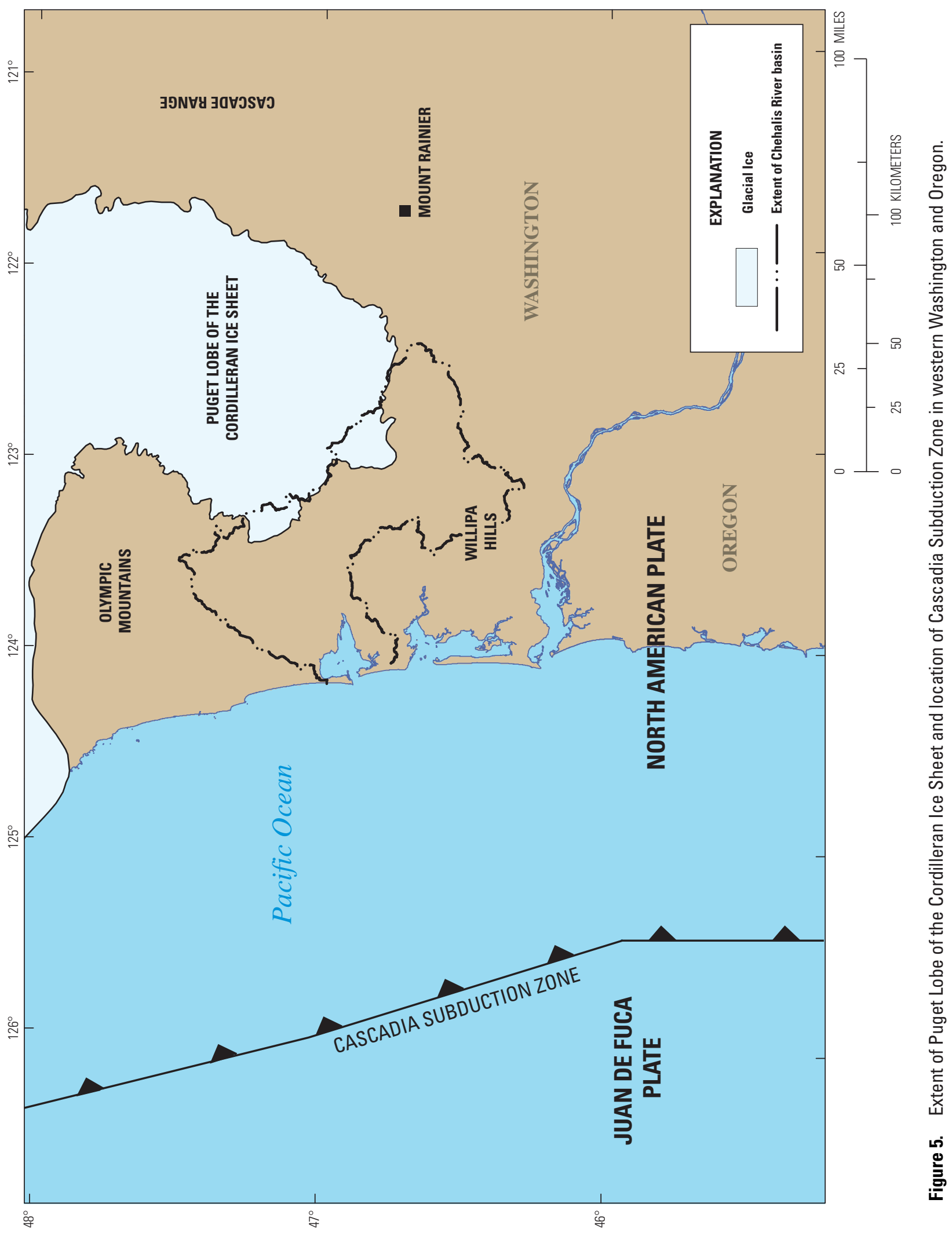




\section{Hydrogeologic Setting}

Geologic materials capable of yielding water in significant quantities to wells or springs are classified as aquifers, whereas lower permeability geologic materials that limit the movement of groundwater are classified as confining units. The presence or absence of confining units in stratigraphic relation to aquifers determines whether an aquifer is confined or unconfined. Unconfined, or "watertable," aquifers occur where the saturated zone of the aquifer can equilibrate to atmospheric pressure and the upper surface of the aquifer (water table) rises and declines in response to groundwater recharge and discharge. Confined, or "artesian," aquifers are overlain by a lower permeability confining unit that prevents water from equilibrating with atmospheric pressure. The water level in a properly sealed well drilled into a confined aquifer will rise above the top of the aquifer to the level of the potentiometric surface, which is the hydraulic head of the aquifer. The potentiometric surface, like the water table in an unconfined aquifer, rises and declines in response to recharge and discharge of the aquifer. Both unconfined and confined aquifers provide significant sources of groundwater in the Chehalis River basin.

The primary aquifers in the Chehalis River basin are comprised of Pleistocene glacial outwash and Holocene alluvium deposited along the valleys of the Chehalis River and its major tributaries. Intervening deposits of Pleistocene glacial till and fine-grained inter-glacial sediments act as semi-confining to confining layers. The upper portion of the alpine glacial outwash within the uplands of the Chehalis River basin has been weathered to clay, forming a confining unit above the alpine glacial outwash. Although these units act regionally as aquifers and confining layers, a large amount of heterogeneity exists within the Quaternary glacial and non-glacial sediments, resulting in localized areas of high permeability within confining units, or low hydraulic conductivity within aquifers. The areal extent of the hydrogeologic units is determined by the Quaternary topography of the Chehalis River basin and the extent of Pleistocene glaciations of both continental and alpine origins. The Tertiary bedrock, consisting of marine and continental sediments, as well as basalts, have relatively low hydraulic conductivities, forming a low permeability basal unit.

\section{Hydrogeologic Units}

Hydrogeologic units were differentiated on the basis of the lithologic properties, hydrologic characteristics, and relative stratigraphic position of rocks and sediments in the Chehalis River basin. Five hydrogeologic units above a low-permeability basal bedrock unit were identified in the Chehalis River basin (pl. 1 and table 1) and are described below.

\section{A Aquifer}

The A aquifer extends throughout the major river valleys and lowland prairies of the Chehalis River and its tributaries and comprises the most areally extensive surficial aquifer. This aquifer interacts readily with surficial water features, in general receiving recharge from rivers during the winter when river stages are high, and discharging to rivers in the summer when river stages are low. This unit contains silt, sand, gravel, and coarser alluvial sediments of glacial and non-glacial origin. The youngest sediments in the A aquifer are coarse-grained channel and fine-grained overbank deposits of modern rivers, which are distributed across the floodplain of the Chehalis River and its tributaries. Modern alluvium overlies and is in direct hydrologic connection with glacial outwash from alpine glaciers, outwash from the Puget lobe of the Cordilleran Ice Sheet, and glacio-lacustrine sediment deposited in pro-glacial lakes.

Although significant heterogeneity exists within the A aquifer, including the presence of local confining layers, several generalizations about the character and hydraulic properties of sediments within this aquifer can be made. First, within the Chehalis River valley north of Centralia and the prairies surrounding Scatter Creek and the Black River, advance and recessional glacial outwash deposited during the Vashon stade (glacial readvance) of the Cordilleran Ice Sheet comprise a distinct coarse, well-sorted portion of the A aquifer. Second, south of Centralia, the aquifer is comprised of fine-grained sediment and poorly sorted and weathered alpine glacial outwash of Hayden Creek age (140 Kya), forming terraces in the Newaukum River and Chehalis River valleys. Pre-Vashon outwash units in the D undifferentiated deposits are in hydrologic connection with the A aquifer and are difficult to distinguish in well logs; therefore, the $\mathrm{D}$ undifferentiated deposits also are included in the A aquifer. Holocene beach deposits also are included in the A aquifer. Bedrock and pre-Vashon till layers within the C undifferentiated deposits form the basal confining unit of this aquifer.

\section{B Confining Unit}

The B confining unit is distributed in the northern part of the Chehalis River basin and is comprised of unsorted and unstratified clay- to boulder-sized particles. Irregularly distributed layers of sand and gravel containing small amounts of groundwater occur locally. Although some local deposits of sand and gravel produce local aquifers, the B unit primarily is comprised of fine-grained sediments, and acts as a confining unit. This unit was deposited during the last glacial advance at the southern margin of the Puget Lobe of the Cordilleran Ice Sheet. The Black Hills separates two distinct areas of till and end moraines that comprise the B confining unit. 
Table 1. Hydrogeologic units in the Chehalis River basin, southwestern Washington.

[Hydrogeologic units defined in this study are delineated in plate 1. Hydrogeologic units of previous studies are defined in cited references. Abbreviations: -, not differentiated]

\begin{tabular}{|c|c|c|c|c|c|c|c|c|c|}
\hline \multirow[b]{2}{*}{ Period } & \multirow[b]{2}{*}{ Epoch } & \multirow[b]{2}{*}{$\begin{array}{l}\text { Hydrogeologic } \\
\text { units defined } \\
\text { in this study }\end{array}$} & \multirow[b]{2}{*}{\begin{tabular}{|c|} 
Range of \\
thickness \\
[estimated \\
average \\
thickness] (feet)
\end{tabular}} & \multirow[b]{2}{*}{$\begin{array}{l}\text { Number of } \\
\text { wells open } \\
\text { to unit }\end{array}$} & \multicolumn{5}{|c|}{ Hydrogeologic units of previous studies } \\
\hline & & & & & $\begin{array}{l}\text { Drost } \\
\text { (1998) }\end{array}$ & $\begin{array}{l}\text { Pitz and } \\
\text { others } \\
(2005)\end{array}$ & $\begin{array}{l}\text { Weigle and } \\
\text { Foxworthy } \\
\text { (1962) }\end{array}$ & $\begin{array}{l}\text { Eddy } \\
\text { (1966) }\end{array}$ & $\begin{array}{c}\text { Noble and } \\
\text { Wallace } \\
\text { (1966) }\end{array}$ \\
\hline \multirow{5}{*}{ 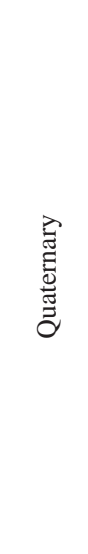 } & 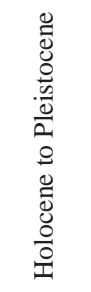 & A & $4-150[20]$ & 100 & Qvr & $\begin{array}{l}\text { Qa, Qgo(g), } \\
\text { Qapo(h) }\end{array}$ & $\begin{array}{l}\text { Qal, Qt, Qo, } \\
\text { Qnt, Qlc }\end{array}$ & $\begin{array}{l}\text { Qal, Qb, Qtv, } \\
\text { Qto }\end{array}$ & $\begin{array}{l}\text { Qal, Qvr, } \\
\text { Qvr1 }\end{array}$ \\
\hline & \multirow{4}{*}{ 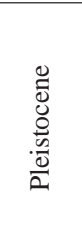 } & B & $5-52[21]$ & 0 & Qvt, Qvrm & - & - & - & Qvm, Qvt \\
\hline & & $\mathrm{C}$ & $25-42[36]$ & 18 & Qva & - & - & - & Qva \\
\hline & & $\mathrm{D}$ & 16-203 [91] & 41 & - & $\begin{array}{l}\text { Qapo(lh), } \\
\text { Qal }\end{array}$ & Qlh & QTu & Qlh \\
\hline & & $\mathrm{E}$ & $18-15[100]$ & 42 & Qf,Qc,TQu & Qago(g) & - & - & $\begin{array}{l}\text { Qss1, Qss2, } \\
\text { Qk, Qpu }\end{array}$ \\
\hline 态 & 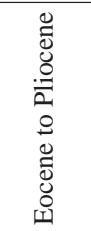 & BDRK & Not applicable & 149 & $\mathrm{~Tb}$ & $\begin{array}{l}\text { Mc(w), } \\
\text { Tb(bslt), } \\
\text { Tbu, Qal }\end{array}$ & $\mathrm{Tu}, \mathrm{Tcr}$ & $\mathrm{Tu}$ & Ts, Tv \\
\hline
\end{tabular}

\section{Aquifer}

The $\mathrm{C}$ aquifer is comprised primarily of well-sorted sand, gravel, and cobble-sized sediment that was deposited as advance glacial outwash during the Vashon Stade of the Fraser Glaciation. Pre-Vashon age outwash in hydrologic connection also is included in the $\mathrm{C}$ aquifer. The $\mathrm{C}$ aquifer is confined by the B confining unit in the northern part of the Chehalis River basin.

\section{Undifferentiated Aquifers and Confining Units}

The D unit is comprised of Pre-Vashon tills and outwash sequences deposited in the northern Chehalis River basin as far south as Centralia. Groundwater within the D unit occurs under confined conditions within coarse-grained outwash sequences that are separated from stratigraphically higher aquifers $\mathrm{A}$ and $\mathrm{C}$ by thin till layers. Multiple aquifers and confining units within the D unit may exist where they have not been eroded and have not been differentiated because they are not laterally continuous. Outwash of this unit is included within the $\mathrm{A}$ and $\mathrm{C}$ aquifers when in direct hydrologic connection with those aquifers.

\section{E Aquifer}

Alpine glacial outwash emanating from the Cascade and Olympic Mountains comprises the E aquifer on the bedrock uplands of the Chehalis River basin. Several episodes of alpine glaciation have been documented since the early Pleistocene, and their deposits consist of Cascade and Olympic-derived Tertiary volcanic and sedimentary rocks, including siltstones, sandstones, and conglomerates. The top portions of these deposits have been extensively weathered into clay, confining groundwater where this unit is saturated. 


\section{BDRK Low Permeability Basal Bedrock Unit}

The Tertiary bedrock (BDRK) forms the basal confining unit of the groundwater-flow system and is relatively impermeable in relation to the unconsolidated sediments stratigraphically above it. Marine and non-marine siltstones, sandstones, and conglomerates locally containing coal beds comprise the Tertiary bedrock unit along with intrusive and extrusive volcanic rocks. Bedrock locally yields water sufficient for domestic use through fracture flow. In the southern part of the Chehalis River basin, appreciable quantities of groundwater are contained within sandstone interbeds of the inferred non-marine Miocene Wilkes Formation, which are confined by overlying clay layers (Pitz and others, 2005). This groundwater may be under artesian pressure where it is present.

\section{Hydraulic Conductivity}

Hydraulic conductivity (the ability of a material to transmit water) depends on the physical properties of the material, including the size, sorting, shape, and compaction of particles. The glacial and alluvial sediments that form the primary aquifers and confining layers within the Chehalis River basin have a large degree of heterogeneity of these physical properties, creating variations of hydraulic conductivity ranging over several orders of magnitude. The magnitude and distribution of horizontal hydraulic conductivities were estimated for wells where specific capacity data (water-level drawdown over time after pumping a well for a specified period of time) were available from drillers' logs. Wells with less than 2 hours of pumping during a specific-capacity test were excluded from analysis. Hydraulic conductivity was estimated from specific capacity tests using one of two sets of equations, depending on whether the well was completed as an open-ended casing, or a screened/ perforated interval.

An equation developed by Bear (1979) was modified for spherical flow to an open-ended well:

$$
K_{h}=\frac{Q}{4 \pi s r},
$$

where

$K_{h}$ is horizontal hydraulic conductivity, in feet per day;

$Q$ is the pumping rate, or discharge, of the well, in cubic feet per day;

$s$ is the drawdown in the well, in feet; and

$r$ is the radius of the well, in feet.
This equation includes the assumption that horizontal and vertical hydraulic conductivities are equal. This assumption is likely violated because horizontal hydraulic conductivity is likely greater than vertical hydraulic conductivity in aquifers in the Chehalis River basin. Therefore, this equation may underestimate $K_{h}$ values.

For wells with a perforated interval, $K_{h}$ was calculated as the quotient of the transmissivity $(T)$, in days, and the aquifer thickness approximated by the length of the perforated interval, in feet. The modified Theis equation (Ferris and others, 1962) was used to calculate transmissivity for perforated interval wells:

$$
s=\frac{Q}{4 \pi s T} \ln \frac{2.25 T t}{r^{2} S}
$$

where

$s$ is the drawdown in the well, in feet;

$Q$ is the pumping rate, or discharge, of the well, in cubic feet per day;

$T$ is the transmissivity of the hydrogeologic unit, in days;

$t$ is the length of time the well was pumped, in days;

$r$ is the radius of the well, in feet;

$S$ is the storage coefficient, a dimensionless number, assumed to be 0.0001 for confining layers; and 0.1 for aquifers.

This equation, which assumes horizontal flow, does not account for flow from above or below the perforated interval, and may result in an overestimation of hydraulic conductivity.

Horizontal hydraulic conductivities of the hydrogeologic units of the Chehalis River basin vary over several orders of magnitude (table 2). Values of $K_{h}$ were greatest for the unconsolidated alluvial and Puget Lobe glacial outwash aquifers ( $\mathrm{A}, \mathrm{C}$, and $\mathrm{D})$, and were smaller for the $\mathrm{E}$ aquifer, which represents older Cascade and Olympic-mountain derived glacial outwash that has been deeply weathered to clay locally. Specific capacity test data were not available for the B hydrogeologic unit, but it is assumed to have a low hydraulic conductivity based on its primarily unsorted texture and lithologic composition. The bedrock low permeability basal unit (BDRK) had the lowest estimated hydraulic conductivities with fracture flow as an important component. 
Table 2. Estimates of hydraulic conductivity in the Chehalis River basin, southwestern Washington.

[Hydrogeologic units are delineated in plate 1. ft/d, feet per day; -, not determined]

\begin{tabular}{|c|c|c|c|c|}
\hline \multirow{2}{*}{$\begin{array}{l}\text { Hydrogeologic } \\
\text { unit }\end{array}$} & \multirow{2}{*}{$\begin{array}{l}\text { Number } \\
\text { of wells }\end{array}$} & \multicolumn{3}{|c|}{$\begin{array}{l}\text { Horizontal hydraulic conductivity } \\
\text { (ft/d) }\end{array}$} \\
\hline & & Minimum & Maximum & Median \\
\hline \multicolumn{5}{|c|}{$\begin{array}{l}\text { Estimated from specific-capacity data } \\
\text { for perforated interval wells }\end{array}$} \\
\hline A aquifer & 11 & 2.2 & 399.9 & 66.3 \\
\hline B confining unit & 0 & - & - & - \\
\hline $\mathrm{C}$ aquifer & 2 & 1.1 & 88.2 & 44.6 \\
\hline D undifferentiated & 2 & 8.9 & 490.6 & 249.8 \\
\hline E aquifer & 2 & 0.2 & 1.8 & 1 \\
\hline $\begin{array}{l}\text { BDRK basal confining } \\
\text { unit }\end{array}$ & 15 & 0.001 & 1.5 & 0.1 \\
\hline \multicolumn{5}{|c|}{$\begin{array}{l}\text { Estimated from specific-capacity data } \\
\text { for open ended wells }\end{array}$} \\
\hline A aquifer & 3 & 122.5 & 229.8 & 122.5 \\
\hline B confining unit & 0 & - & - & - \\
\hline $\mathrm{C}$ aquifer & 0 & - & - & - \\
\hline D undifferentiated & 2 & 153.2 & 294.1 & 223.7 \\
\hline E aquifer & 1 & - & - & 36.8 \\
\hline $\begin{array}{l}\text { BDRK basal confining } \\
\text { unit }\end{array}$ & 5 & 0.8 & 76.6 & 9.7 \\
\hline
\end{tabular}

\section{Groundwater Movement and Fluctuation}

A regional water-level contour map for the surficial aquifers, including the $\mathrm{A}$ and $\mathrm{D}$ units, was drawn from water levels measured between July and September 2009 to estimate general directions of horizontal groundwater flow (fig. 6). Wells completed in the D aquifer were included within the delineation of this map because pre-Vashon age glacial till layers confining groundwater in the $\mathrm{D}$ unit are discontinuous and sometimes absent, putting A and D in close hydrologic connection. Groundwater flows perpendicular to water-level contours (water-table altitude in an unconfined aquifer) from areas of higher to lower water levels. In general, horizontal groundwater flow follows the contours of the surface-water drainage of the Chehalis River and its tributaries, flowing from the headwaters towards Grays Harbor. Hydraulic gradients are relatively steep in the tributary valleys such as the Newaukum Valley (about $23 \mathrm{ft} / \mathrm{mi}$ ) and flatter in the alluvial valley of the central Chehalis River (about $6 \mathrm{ft} / \mathrm{mi}$ ). The lowest groundwater levels in the surficial aquifers occur in the lower Chehalis
River basin near the confluence of the Satsop and Chehalis Rivers. The tides of Grays Harbor may account for elevated groundwater levels in the lower Chehalis River basin.

Groundwater levels in the Chehalis River basin fluctuate seasonally and over shorter timescales in response to changes in aquifer recharge and discharge driven by storm events, river stage, and tidal fluctuations. In general, water levels rise during autumn and winter when precipitation is highest and water use is lowest; conversely, water levels decline during the spring and summer when precipitation is lower and water use increases. Water levels typically were lowest in late summer to early fall. Water levels measured in 14 wells completed in the surficial aquifer fluctuated by as little as $4.8 \mathrm{ft}$ to as much as $16.8 \mathrm{ft}$ during water year 2010. The largest groundwater fluctuation occurred in well 15N/03W-03A02P3 (fig. 7A). This well was the farthest from a river of the monitored wells and was completed within the $\mathrm{D}$ aquifer confined beneath a till of pre-Vashon Age. Rivers and other surface-water features may attenuate water-level fluctuations within riparian wells with direct connection to surface-water systems because they can provide aquifer recharge when the aquifer levels are low and receive aquifer discharge when aquifer levels are high.

Three sites within the monthly monitoring network were constructed with three nested wells open at different levels within the $\mathrm{D}$ unit across multiple low-permeability layers. This allowed quantification of vertical gradients at these three locations. At the first site containing wells $15 \mathrm{~N} / 03 \mathrm{~W}-$ 03A02P1, 15N/03W-03A02P2, and 15N/03W-03A02P3, the water level measured at the deepest well 15N/03W-03A02P1 (125 ft deep) was consistently lower (0.46- $0.99 \mathrm{ft}$; median: $0.74 \mathrm{ft}$ ) than the water level measured at the shallowest piezometer 15N/03W-03A02P3 (52 ft deep) indicating downward movement of water throughout the year (fig. 7A). At the second site containing wells $15 \mathrm{~N} / 03 \mathrm{~W}-10 \mathrm{D} 02 \mathrm{P} 1$, $15 \mathrm{~N} / 03 \mathrm{~W}-10 \mathrm{D} 02 \mathrm{P} 2$, and 15N/03W-10D02P3, water levels measured at monthy intervals within the deepest well (15N/03W-10D02P1; $83 \mathrm{ft}$ deep) also were consistently lower than the shallowest well (15N/03W-10D02P3; $35 \mathrm{ft}$ deep) by 0.05-0.37 ft (median: $0.21 \mathrm{ft}$; fig. $7 \mathrm{~B}$ ). Water-level gradients determined at the third site containing wells $16 \mathrm{~N} / 03 \mathrm{~W}$ 33P01P1, 16N/03W-33P01P2, and 16N/03W-33P01P3 agreed with the first two sites with water levels at the deepest well 16N/03W-33P01P1 (93 ft deep) consistently lower than water levels within the shallowest well (16N/03W-33P01P3) (46 ft deep ) by $0.23-2.4 \mathrm{ft}$ (median: $0.29 \mathrm{ft}$; fig. $7 C$ ). These waterlevel differentials show that vertical flow does occur through confining to semi-confining units within the unconsolidated sediments of the D Unit. 


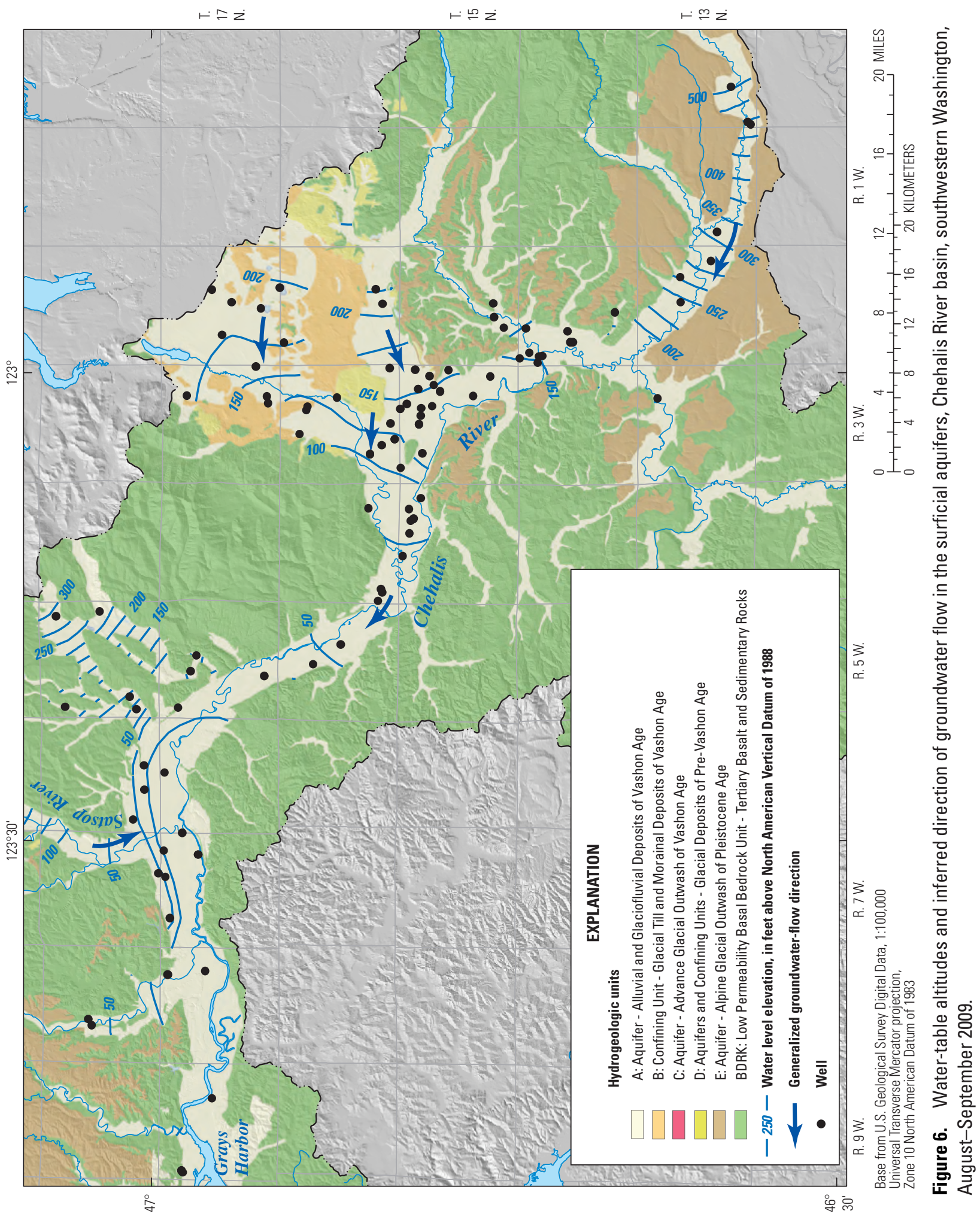




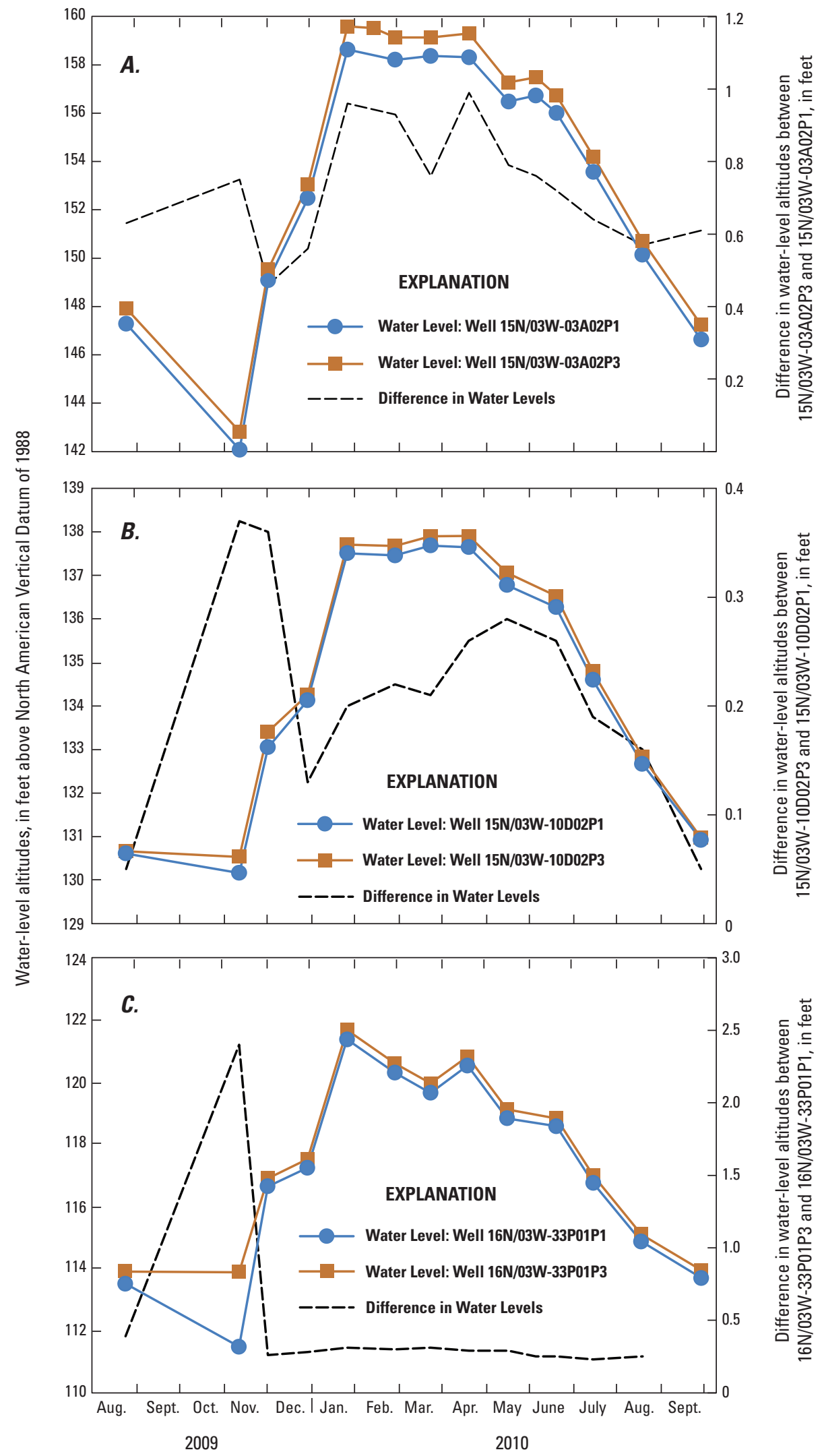

Figure 7. Water-level altitudes for nested wells $(A) 15 \mathrm{~N} / 03 \mathrm{~W}-03 \mathrm{~A} 02 \mathrm{P} 1$ and 15N/03W-03A02P3, $(B)$ 15N/03W-10D02P1 and 15N/03W-10D02P3, and $(C)$ 16N/03W-33P01P1 and 16N/03W-33P01P3, Chehalis River basin, Washington, August 2009-0ctober 2010. 


\section{Groundwater/Surface-Water Interactions}

Surface water in rivers and lakes can readily interact with groundwater in aquifers, resulting in the exchange of appreciable quantities of water and solutes. This exchange, or seepage, provides recharge of aquifers and maintenance of streamflows, and has the potential to affect the quality of groundwater and surface-water bodies. When the water table in an unconfined aquifer is higher than the river stage, an upward hydraulic gradient drives the movement of water from the aquifer to the river, resulting in a gaining stream; conversely, a downward hydraulic gradient exists when the river elevation is higher than the water table, causing the water to seep from river to the underlying aquifer.

The Chehalis River is a rainfall-runoff dominated system in which the seasonal variation in streamflow is greater than 100 percent of the mean annual streamflow of $4,049 \mathrm{ft}^{3} / \mathrm{s}$ (fig. 3). The relative contribution of groundwater to streamflow varies significantly between seasons. Pitz and Sinclair (1999) calculated baseflow, a measure of groundwater contribution to streamflow, at the Chehalis River at Porter (USGS site No. 12031000). Pitz and Sinclair (1999) determined that baseflow varies from only 45 percent of total streamflow in November to as much as 89 percent of total streamflow in July, when streamflows are near their annual minimum.

A series of streamflow measurements, termed a seepage run, were made to identify gaining and losing reaches in the Chehalis River during summer baseflow conditions in August 2010 when streamflow was at its lowest (fig. 3) and the contribution of groundwater as a fraction of streamflow was likely at its annual maximum. Synoptic discharge measurements were made at 41 locations and streamflow gains and losses were calculated for 28 reaches of the Chehalis River from its confluence with the Newaukum River to Oakville, Skookumchuck River, Scatter Creek, and Black River from August 17-19, 2010. The seepage reaches in this study are within the extent of a 2007 USGS seepage investigation (Ely and others, 2008) and three previous studies (Sinclair and Hirschey, 1992; Pitz and others, 2005; Ely and others, 2008). Additional streamflow gaging locations were incorporated within this study, resulting in a more detailed seepage evaluation, with 18 seepage reaches along the central Chehalis River, which ranged in length from 0.8 to 8.4 mi. Additionally, wells within the surficial aquifer were measured at hourly and monthly intervals from November 2009 to August 2010 to characterize the magnitude and timing of seasonal fluctuations in groundwater levels in relation to exchanges with surface-water bodies and recharge from precipitation.
The Chehalis River gained $56.8 \pm 23.7 \mathrm{ft}^{3} / \mathrm{s}$ over 32.8 river miles $\left[1.7\left(\mathrm{ft}^{3} / \mathrm{s}\right) / \mathrm{mi}\right]$ from the upstream to downstream extent of the seepage run, but most of the incremental gains and losses were within compounded measurement error (table 3; fig. 8). Only one seepage reach (fig. 8; reach F) showed a net gain of $29.0 \pm 25.5 \mathrm{ft}^{3} / \mathrm{s}$ [17.1 ( $\left.\left.\mathrm{ft}^{3} / \mathrm{s}\right) / \mathrm{mi}\right]$, and only two seepage reaches showed net losses of $-48.3 \pm 24.5 \mathrm{ft}^{3} / \mathrm{s}\left[-48.3\left(\mathrm{ft}^{3} / \mathrm{s}\right) / \mathrm{mi}\right]$ (reach O) and $-23.0 \pm 22.5 \mathrm{ft} 3 / \mathrm{s}\left(-17.7\left(\mathrm{ft}^{3} / \mathrm{s}\right) / \mathrm{mi}\right]$, (reach $\left.\mathrm{K}\right)$, which were larger in magnitude than the associated compounded measurement errors. The small number of significant gains and losses relative to compounded measurement error indicates diffuse groundwater inflow between reaches $\mathrm{D}$ and $\mathrm{G}$.

Ely and others (2008) report that the largest river-aquifer exchanges on the Chehalis River observed in September 2007 occured downstream of Grand Mound where the Chehalis River enters a broad prairie of low relief. Mean daily streamflow was approximately $120 \mathrm{ft}^{3} / \mathrm{s}$ lower during the September 2007 seepage run $\left(329 \mathrm{ft}^{3} / \mathrm{s}\right.$ at Chehalis River at Porter, Washington: 12031000) than during the August 2010 seepage run (449 $\mathrm{ft}^{3} / \mathrm{s}$ at Chehalis River at Porter, Washington: 12031000). During the August 2010 seepage run, the Chehalis River remained near neutral upstream of river mile 58.8 before gaining $29 \mathrm{ft}^{3} / \mathrm{s}$ within seepage reach F (fig. 9; RM 57.1-58.8). Seepage reach $F$ had the highest gradient $(0.0012 \mathrm{ft} / \mathrm{ft})$ within the extent of the seepage run (mean gradient: $0.0005 \mathrm{ft}$ / $\mathrm{ft}$ ) potentially gaining streamflow by intersecting the water table of the underlying unconfined aquifer. A longer seepage reach measured in September 2007 that encompassed seepage reaches $\mathrm{E}, \mathrm{F}, \mathrm{G}$, and $\mathrm{H}$ gained $76.9 \mathrm{ft}^{3} / \mathrm{s}$ suggesting that this section of the Chehalis River consistently gains streamflow from the underlying aquifer during low-flow conditions (fig. 9). The Chehalis River exchanged comparable amounts of water with the underlying aquifer in August 2010 as it did in September 2007 (ig. 9). Several notable exceptions exist including losses within seepage reaches I and R measured in 2007 that were not measured in 2010 and a loss in seepage reach $\mathrm{O}$ measured in 2010 that was not observed in 2007. This suggests temporal variability in river-aquifer exchanges within the centreal Chehalis River basin during low-flow conditions.

The central Chehalis River lacks common geologic and geomorphic controls that focus large exchange of groundwater and surface water. Changes in unconsolidated aquifer thickness, contact of lithologic units that differ markedly in hydraulic conductivity, and channel forms that increase hydraulic gradient between a river and shallow groundwater promote groundwater/surface-water exchanges (Konrad, 2006). Within the extent of the seepage run the depth of the alluvial sediment remained relatively constant (pl. 1, section $B-B$ ') precluding seepage gains associated with thinned alluvial sediments at the outlets of structural bedrock basins. 


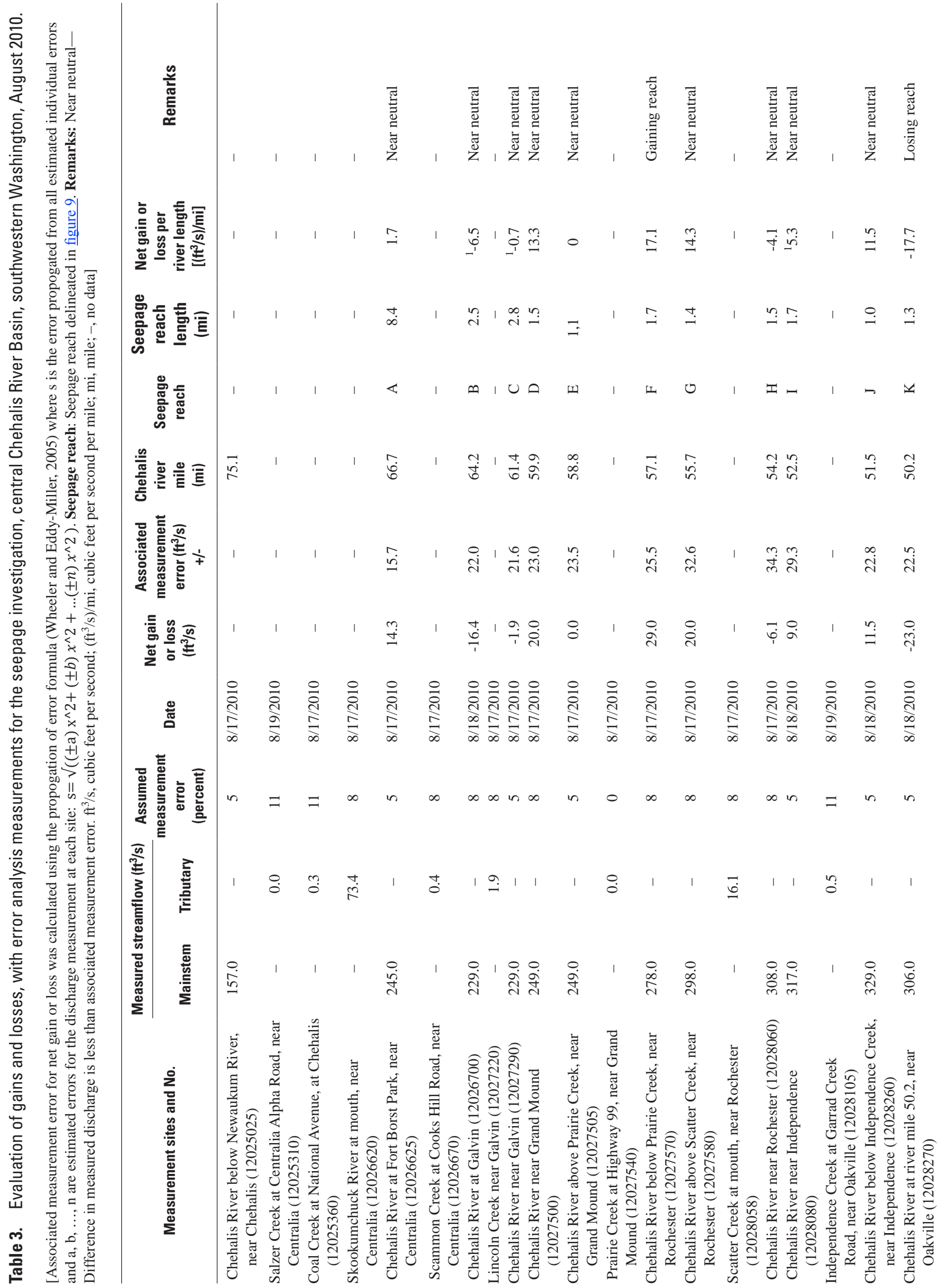




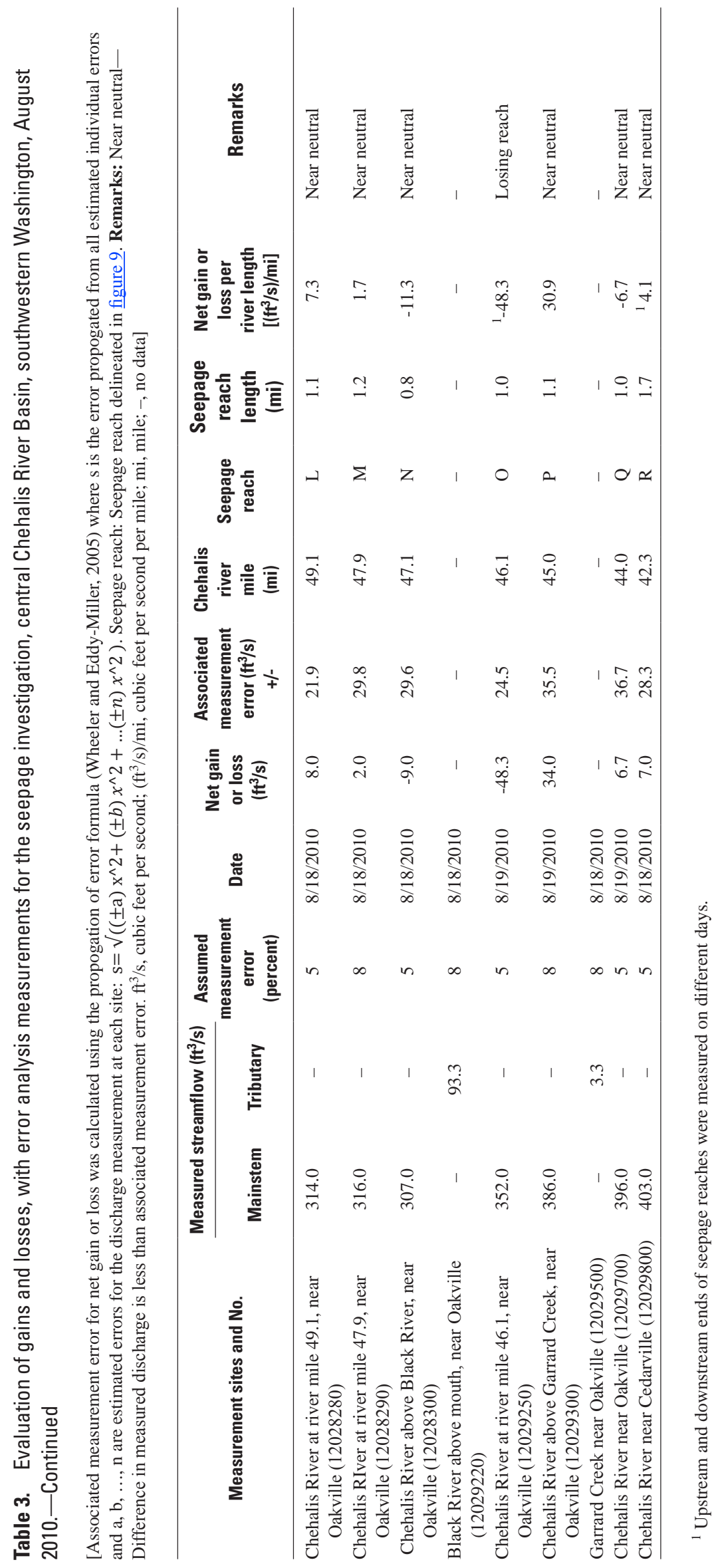




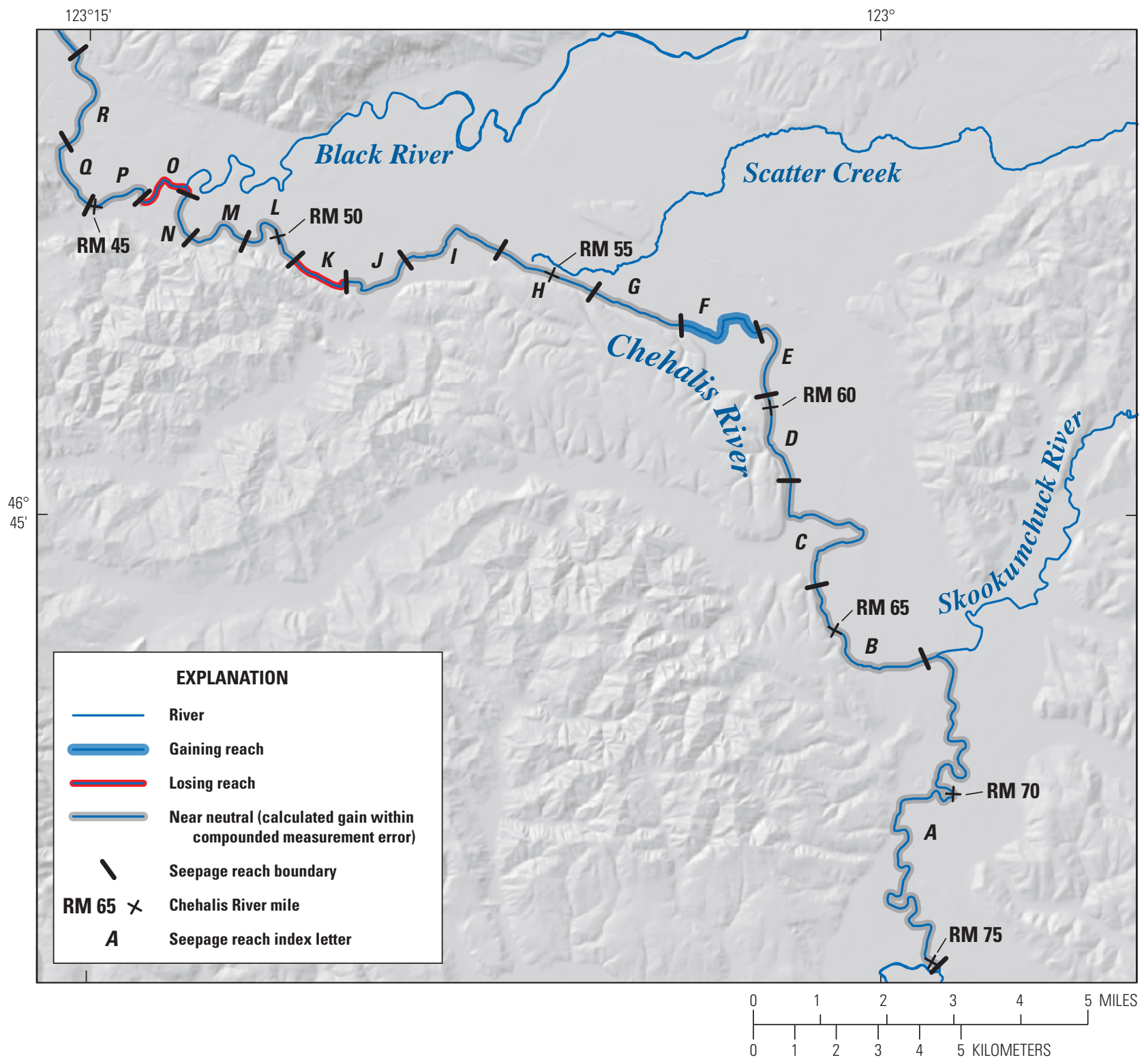

Figure 8. Streamflow gaining, losing, and near-neutral reaches, central Chehalis River Basin, southwestern Washington, August 2010. 


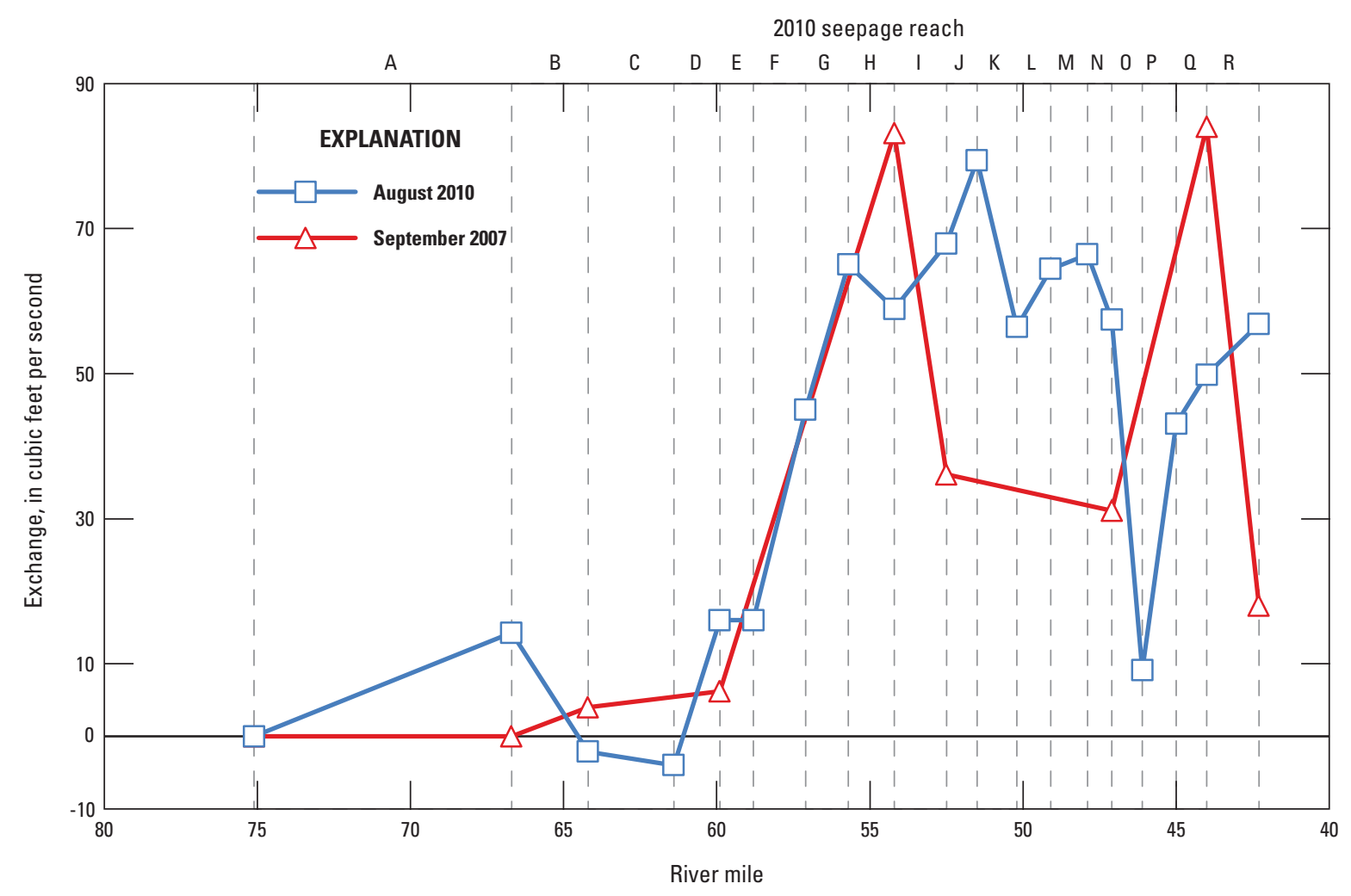

Figure 9. Cumulative river-aquifer exchanges for the central Chehalis River, southwestern Washington, August 2010 and September 2007. 
The central Chehalis River flows over alluvial and glacio-fluvial sediments, which do not differ markedly in their hydraulic conductivity and therefore do not concentrate groundwater input along the Chehalis River. Finally, the significant tributaries that join the central Chehalis River, such as the Skookumchuck River, Scatter Creek, and the Black River flow over low-gradient topography formed during the last glacial retreat; the Chehalis River does not intercept any steep gradient tributaries that deposit alluvial that promote recharge of the main valley aquifer that could be subsequently intercepted by the mainstem Chehalis River.

Streamflow gains and losses also were estimated for several tributaries of the central Chehalis River including the Skookumchuck River, Scatter Creek, and Black River (table 4). Ungaged diversions and return flows between streamflow measurements may cause an overestimation of losses or gains, respectively. In particular, the reported gain of $6.5\left(\mathrm{ft}^{3} / \mathrm{s}\right) / \mathrm{mi}$ at the upstream-most seepage reach of Scatter Creek is likely the result of unmeasured hatchery return flows to Scatter Creek, which was inaccessible for measurement during the seepage run.

The groundwater levels within wells completed in the surficial aquifers near the Chehalis River fluctuated with the changes in river stage (fig. 10); note that groundwater levels and stream stage are not referenced to common datums). The changes in river stage were probably driven by precipitation events in the upper Chehalis River and tides within the lower Chehalis River. Wells completed within the unconfined A aquifer in close proximity to the Chehalis River and its tributaries, notably well 14N/02W-07B02, located at less than $0.1 \mathrm{mi}$ from the Chehalis River, fluctuated directly with river stage (fig. 10A). Groundwater levels in well 14N/02W-07B02 responded to changes in gage height within several hours as a result of the high hydraulic conductivities of the overlying sediments and lack of confining layers. The nearby well 14N/02W-06C02 (fig. 10B), which was also completed in the A aquifer fluctuates with the river stage, but the amplitude of the fluctuations was lower because it is further away (1.0 mi) from the Chehalis River. Similar relationships between river stage and groundwater levels in wells 14N/02W-07B02 and 14N/02W-06C02 were reported by Pitz and others (2005). Wells 15N/04W-02N03 (fig. 10C), 15N/04W-03R02 (fig. 10D) and 15N/03W-08B01 (fig. 10E) are completed in the A aquifer and show similarly muted groundwater-level responses to fluctuations in stream stage. Wells completed at greater distances away from the Chehalis River (for example, $15 \mathrm{~N} / 03 \mathrm{~W}-03 \mathrm{~A} 02 \mathrm{P} 3 ; 2.0 \mathrm{mi}$ ) have large seasonal fluctuations in water levels likely related to groundwater withdrawals during the summer and recharge from infiltrating precipitation during the fall and winter. Wells completed at greater distances from the Chehalis River have muted responses to fluctuations in river stage (fig. 10F) showing the attenuation of groundwater/surface-water interactions away from surfacewater bodies.

The stage of the Chehalis River is influenced by ocean tides downstream of the confluence of the Chehalis River with the Satsop River as apparent at USGS streamflow gage 12035100. Water-level fluctuations of well 17N/07W-08K02 (fig. 11) completed in the A unit located less than $0.1 \mathrm{mi}$ from the Chehalis River near its confluence with the Wynoochee River were similar to the tidally influenced fluctuations of the stage measured at a nearby USGS streamflow gage (12035100). Groundwater levels follow variations in tidally influenced river stage and are only attenuated several feet and delayed by several hours relative to the stream stage. 


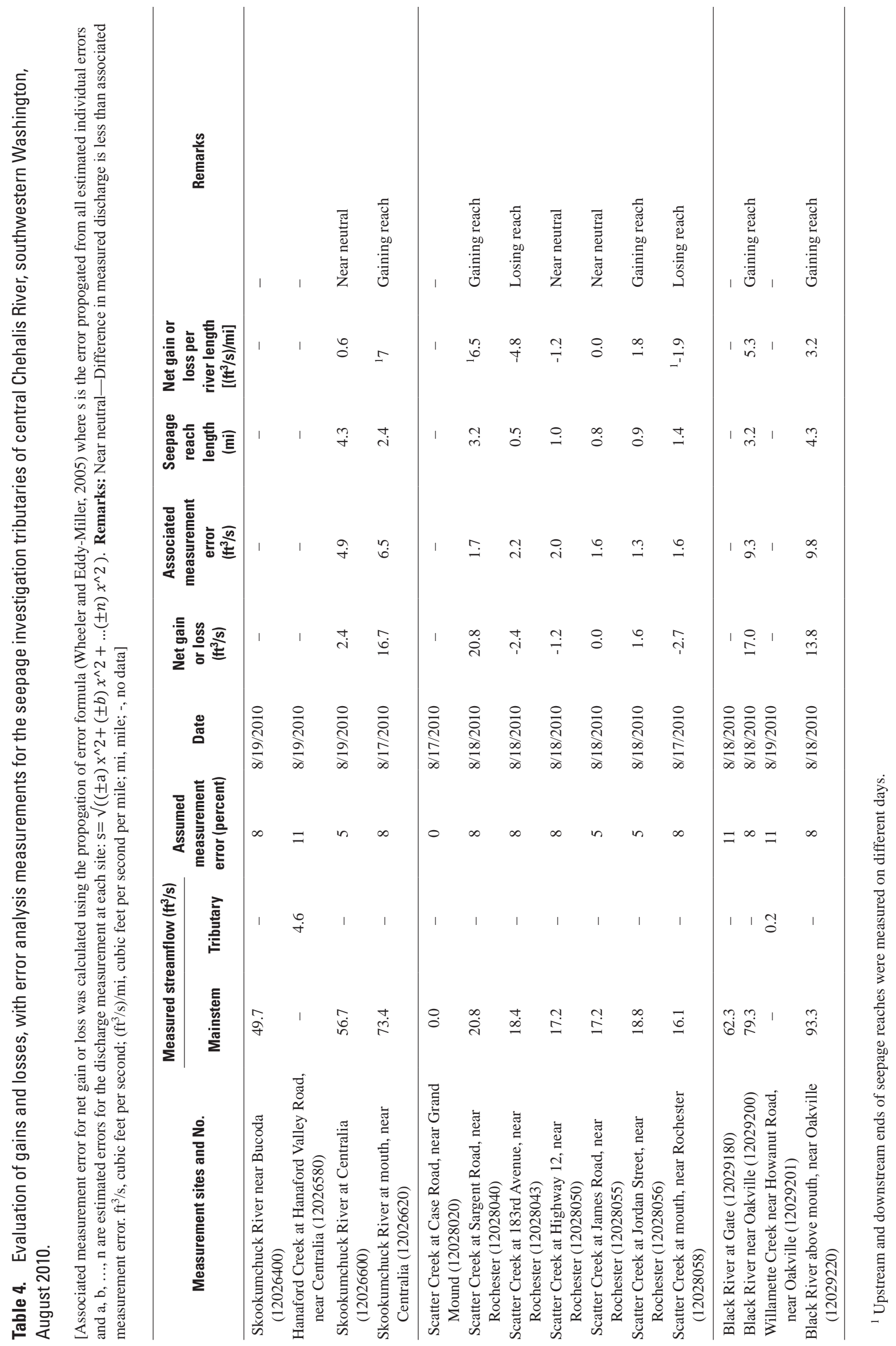




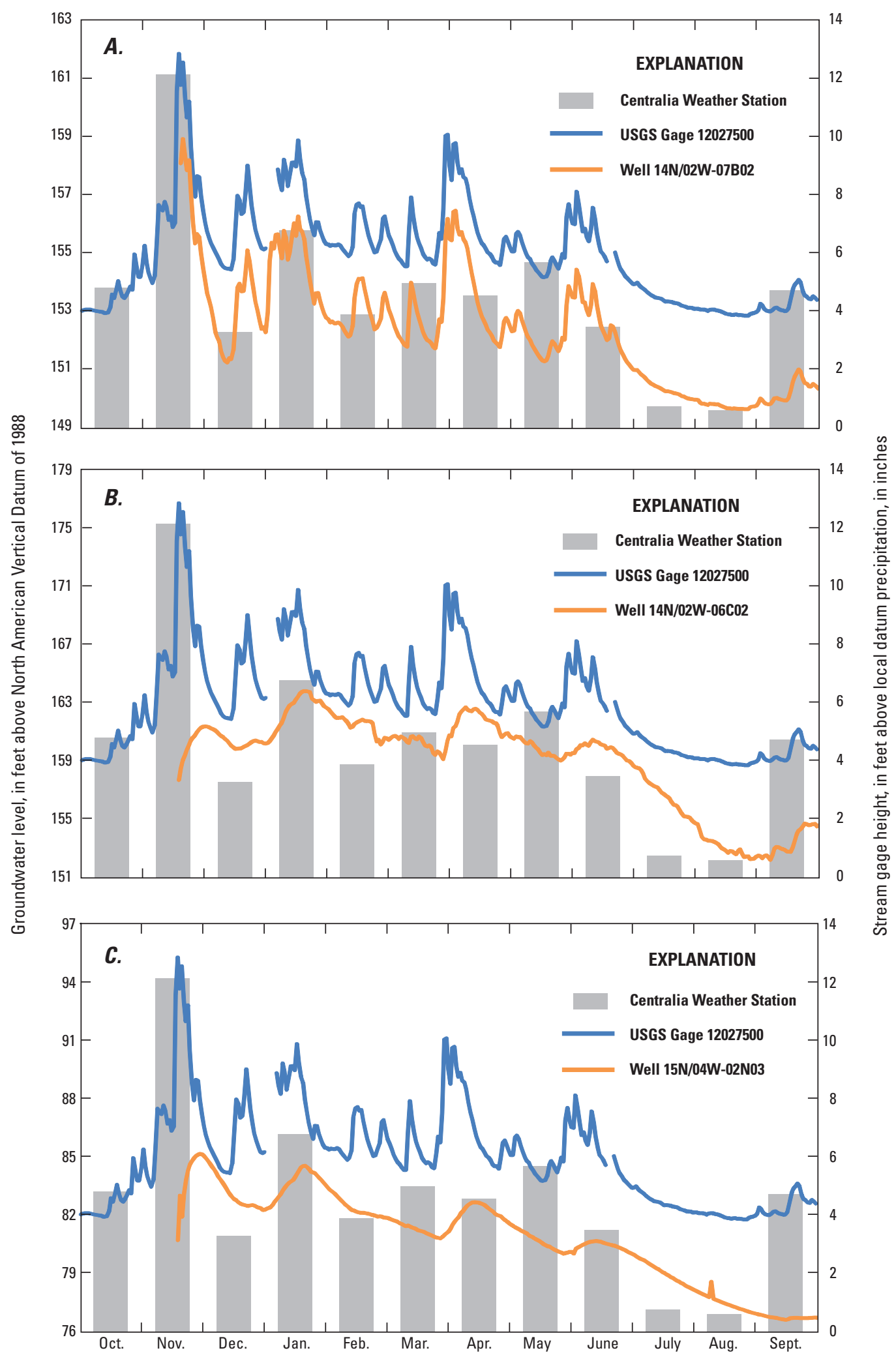

Figure 10. Continuous water levels in wells, stream stage at U.S. Geological Survey streamflow-gaging station 12027500, Chehalis River at Grand Mound, and total monthly precipitation at Centralia, October 2009-September 2010 for wells 14N/02W-07B02 (A), 14N/02W-06C02 (B), 15N/04W-02N03 (C), 15N/04W-03R02 (D), $15 \mathrm{~N} / 03 \mathrm{~W}-08 \mathrm{~B} 01(E)$, and 15N/03W-03A02P3 (F), Chehalis River basin, southwestern Washington. 


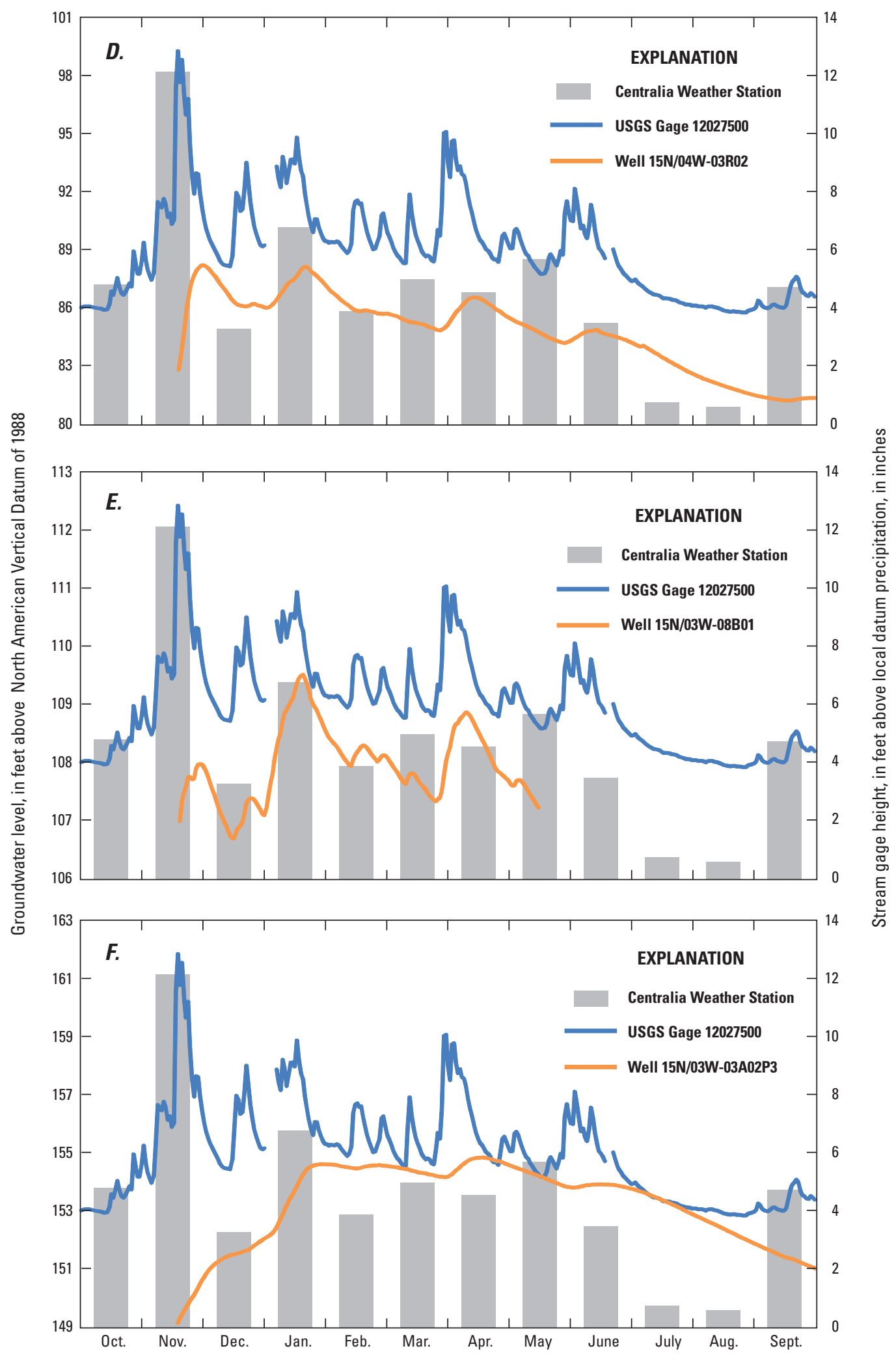

Figure 10.-Continued 


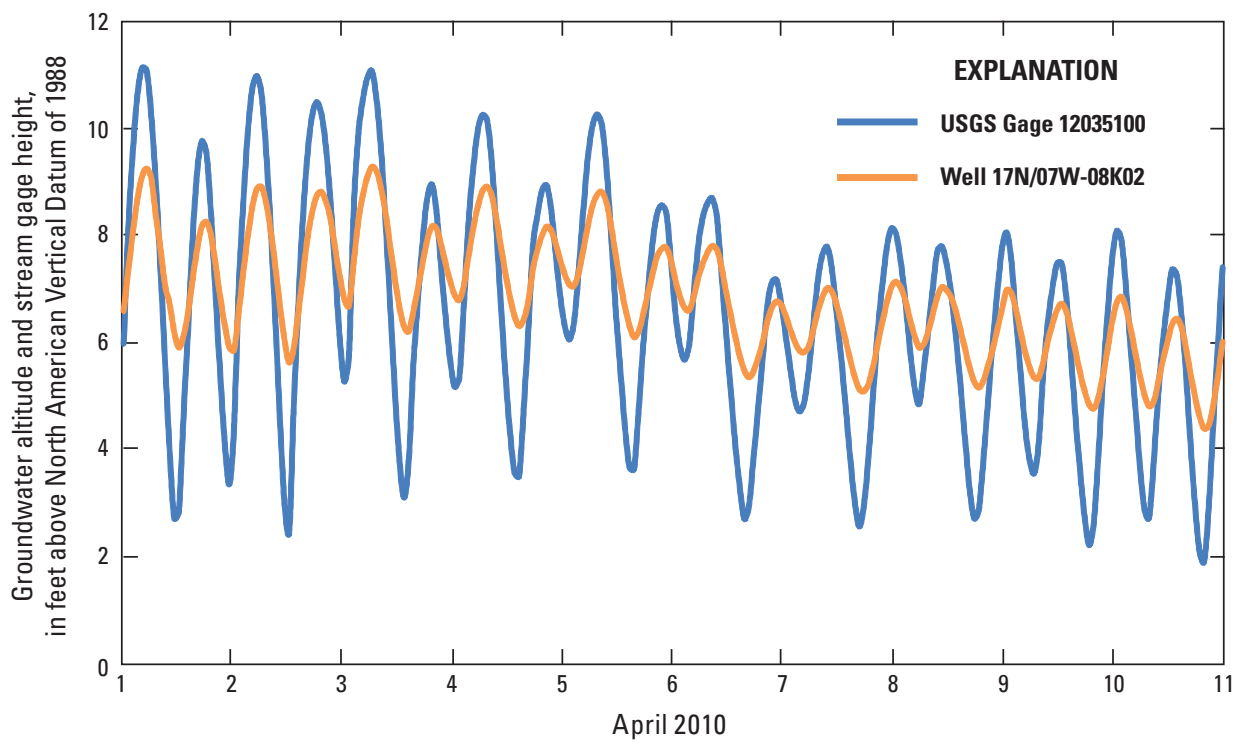

Figure 11. Graph showing water levels in well 17N/07W-08K02 and stream stage at U.S. Geological Survey streamflow-gaging station 12035100, Chehalis River at Montesano, April 1, 2010-April 11, 2010, Chehalis River basin, southwestern Washington. 


\section{Summary and Conclusions}

This study characterized the surficial hydrogeologic framework and groundwater/surface-water interactions within the 2,700-square-mile Chehalis River basin. The broad valleys and prairies of the Chehalis River basin are underlain by recent alluvium and glacial drift and contain most of the significant groundwater resources, agricultural lands, and urban development in the region. The Tertiary sedimentary and volcanic bedrock, which crops out at the surface along much of the Chehalis River basin uplands, has lower hydraulic conductivity than the alluvium and glacial drift and generally is not used as a source of water except for domestic consumption.

The unique position of the Chehalis River basin at the terminus of multiple advances of the Puget Lobe of the Cordilleran Ice Sheet resulted in a complex and heterogeneous deposition of sediments throughout the Quaternary Period. Aquifers within the outwash units deposited by meltwater streams that drained the Puget Lobe generally have high hydraulic conductivities. Glacial till, which generally has lower hydraulic conductivity, forms confining units which are often discontinuous because of post-glacial erosion and non-uniform deposition. Multiple advances of alpine glaciers originating in the Olympic and Cascade Mountains during the Pleistocene also deposited significant amounts of glacial outwash on the bedrock uplands of the eastern and northern parts of the Chehalis River basin.

The five hydrogeologic units and low permeability basal bedrock unit presented within this report are an attempt to generalize the Quaternary stratigraphy into a regional hydrogeologic framework, with the recognition that significant local variation exists. A surficial hydrogeologic unit map and two hydrogeologic cross-sections were constructed from existing geologic maps and information from 372 lithostratigraphic logs. Water levels measured during AugustSeptember 2009 were used to construct a water table map and generalized flow directions for the surficial aquifers of the Chehalis River basin.

Interaction between groundwater and surface water is apparent from water-level fluctuations in streams and aquifers and streamflow gains and losses measured during seepage runs. Synoptic streamflow measurements made in August 2010 show an overall gain of $56.8 \pm 23.7$ cubic feet per second over 32.8 river miles (1.7 cubic feet per second per mile) within the central Chehalis River and individual seepage reach gains and losses ranging from -48.3 to 30.9 cubic feet per second per mile. Most gains and losses, however, were less than compounded measurement error suggesting generally diffuse groundwater inflow, but became more pronounced downstream of Grand Mound. The uppermost unconfined aquifer (A unit) exchanges water with the Chehalis River and its tributaries, contributing baseflow during the dry summer months and receiving recharge from surface-water units during the wet winter months. Water levels in wells open to the A unit in close proximity to the surface-water features respond rapidly to changes in stream stage. Near-river wells respond most quickly to stream stage, but water levels also are influenced by other factors. Water levels within surficial aquifers contained by the upper Chehalis River basin respond to changes in stream stage due to storms, while Pacific Ocean tides influence streamflow stage and surficial aquifer water levels in the lower Chehalis River basin downstream of the Satsop River.

\section{Acknowledgments}

The author would like to thank the wellowners within the Chehalis River basin for providing access to their wells and the local, State and Tribal agencies who facilitated access to their well networks including the Washington State Department of Ecology and the Confederated Tribes of the Chehalis Reservation.

\section{References Cited}

Bear, J., 1979, Hydraulics of groundwater: New York, McGraw-Hill, 569 p.

Bretz, J.H., 1913, Glaciation of the Puget Sound region: Washington Geologic Survey Bulletin no. 8, 244 p.

Crandell, D.R., 1963, Paradise debris flow at Mount Rainier, Washington: U.S. Geological Survey Professional Paper 388A, $84 \mathrm{p}$.

Crandell, D.R., and Miller, R.D., 1974, Quaternary stratigraphy and extent of glaciation in the Mount Rainier region, Washington: U.S. Geological Survey Professional Paper 847, 59 p.

Drost, B.W., 2005, Quality-assurance plan for ground-water activities, U.S. Geological Survey, Washington Water Science Center: U.S. Geological Survey Open-File Report 05-1126, 27 p. (Also available at http://pubs.usgs.gov/ of/2005/1126/.)

Drost, B.W., Turney, G.L., Dion, N.P., and Jones, M.A., 1998, Hydrology and quality of ground water in Northern Thurston County, Washington: U.S. Geological Survey Water-Resources Investigations Report 92-4109 [revised], 230 p. (Also available at http://pubs.er.usgs.gov/publication/ wri924109 1994.)

Easterbrook, D.J., 1986, Stratigraphy and chronology of Quaternary deposits of the Puget Lowland and Olympic Mountains of Washington and the Cascade Mountains of Washington and Oregon: Quaternary Science Reviews, v. 5, p. 145-159. 
Eddy, P.A., 1966, Preliminary investigation of the geology and groundwater resources of the lower Chehalis River valley and adjacent areas: Washington Department of Conservation Water Supply Bulletin 30, 70 p.

Ely, D.M., Frasl, K.E., Marshall, C.A., and Reed, F., 2008, Seepage investigation for selected river reaches in the Chehalis River basin, Washington: U.S. Geological Survey Scientific Investigations Report 2008-5180, 12 p. (Also available at http://pubs.usgs.gov/sir/2008/5180/.)

Fasser, E.T., and Julich, R.H., 2010, Groundwater levels for selected wells in the Chehalis River basin, Washington: U.S. Geological Survey Data Series 512. (Also available at http://pubs.usgs.gov/ds/512/.)

Ferris, J.G., Knowles, D.B., Brown, R.H., and Stallman, R.W., 1962, Theory of aquifer tests: U.S. Geological Survey Water-Supply Paper 1536-E, 174 p.

Garrigues, R.S., Sinclair, K., and Tooley, J., 1998, Chehalis River watershed surficial aquifer characterization: Washington State Department of Ecology, Publication No. 98-335, 33 p.

Heaton, T.H., and Kanamori, H., 1984, Seismic potential associated with subduction in the northwestern United States: Bulletin of the Seismological Society of America, v. 74 , no. 3, p. $933-941$.

Homer, C.C., Huang, C., Yang, L., Wylie, B., and Coan, M., 2004, Development of a 2001 national landcover database for the United States: Photogrammetric Engineering and Remote Sensing, v. 70, p. 829-840.

Konrad, C.P., 2006, Location and timing of river-aquifer exchanges in six tributaries to the Columbia River in the Pacific Northwest of the United States: Journal of Hydrology, v. 329, p. 444-470.

Lea, P.D., 1984, Pleistocene glaciation at the southern margin of the Puget Lobe, Western Washington: Master's thesis, University of Washington, 96 p.

Logan, R.L., compiler, 1987, Geologic map of the Chehalis River and Westport quadrangles, Washington: Washington Division of Geology and Earth Resources Open-File Report 87-8, 16 p., 1 plate, scale 1:100,000.

Logan, R.L., 2003, Geologic map of the Shelton 1:100,000 quadrangle, Washington: Washington Division of Geology and Earth Resources Open-File Report 2003-15, 1 sheet, scale 1:100,000.

Logan, R.L., Walsh, T.J., Stanton, B.W., and Sarikhan, I.Y., 2009, Geologic map of the Maytown 7.5-minute quadrangle, Thurston County, Washington: Washington Division of Geology and Earth Resources Geologic Map GM-72, 1 sheet, scale 1:24,000.
National Oceanic and Atmospheric Administration, 2010, Climatological data, annual summary - Washington, 2009: Ashville, North Carolina, National Climatic Data Center, v. 113, no. 13.

Noble, J.R., and Wallace, F.F., 1966. Geology and groundwater resources of Thurston County, Washington, v. 2: Washington Department of Conservation Water-Supply Bulletin 10, $61 \mathrm{p}$.

Oberg, K.A., Morlock, S.E., and Caldwell, W.S., 2005, Quality assurance plan for discharge measurements using acoustic Doppler current profilers: U.S. Geological Survey Scientific Investigations Report 2005-5183, 35 p. (Also available at http://pubs.usgs.gov/sir/2005/5183/.)

Pitz, C.F., and Sinclair, K.A, 1999, Estimated baseflow characteristics of selected Washington rivers and streams: Washington Department of Ecology Water Supply Bulletin No. 60, Publication 99-327, 25 p. + App.

Pitz, C.F., Sinclair, K.A., and Oestreich, A.J., 2005, Washington State groundwater assessment programHydrology and quality of groundwater in the CentraliaChehalis area surficial aquifer: Washington State Department of Ecology, Publication no. 05-03-040, 104 p., 4 pls.

PRISM Group, 2011, Oregon State University, Mean annual precipitation from 1971 to 2000, accessed online at http:// prism.oregonstate.edu/products/matrix.phtml on January 5, 2011.

Rantz, S.E., 1982, Measurement and computation of streamflow, volume 1-Measurement of stage and discharge: U.S. Geological Survey Water-Supply Paper 2175, 284 p. (Also available at http://pubs.usgs.gov/wsp/ wsp2175/.)

Sauer, V.B., and Meyer, R.W., 1992, Determination of error in individual discharge measurements: U.S. Geological Survey Open-File Report 92-144, 21 p. (Also available at http:// pubs.usgs.gov/of/1992/ofr92-144/.)

Schasse, H.W., compiler, 1987, Geologic map of the Centralia quadrangle, Washington: Washington Division of Geology and Earth Resources Open File Report 87-11, 28 p., 1 plate, scale 1:100,000.

Sinclair, K.A., and Hirschey, S.J., 1992, A hydrogeologic investigation of the Scatter Creek/Black River area, southern Thurston County: Master's thesis, Evergreen State College, $192 \mathrm{p}$.

Snavely, P.D. Jr., Brown, R.D. Jr., Roberts, A.E., and Rau, W.W., 1958, Geology and coal-resources of the Centralia-Chehalis district, Washington, with a section on microscopical character of the Centralia-Chehalis coal, by J.M. Schopf: U.S. Geological Survey Bulletin 1053, 159 p. 
Thackray, G.D., 1996, Glaciation and neotectonic deformation on the western Olympic Peninsula, Washington: Phd. thesis, University of Washington, 139 p., 2 plates.

U.S. Geological Survey, 2011, Annual water-data reports: U.S. Geological Survey, accessed July 14, 2011 at http://wdr. water.usgs.gov/.

Washington Division of Geology and Earth Resources, 2005, Digital 1:100,000-scale geology of Washington State, version 1.0: Washington Division of Geology and Earth Resources Open-File Report 2005-3, accessed January 5, 2011 at http://www.dnr.wa.gov/ResearchScience/Topics/ GeosciencesData/Pages/gis data.asp.

Wallace, E.F., and Molenaar, D., 1961, Geology and groundwater resources of Thurston County, Washington, Volume I: Washington Department of Conservation Water Supply Bulletin 10, 254 p.
Weigle, J.M., and Foxworthy, B.L., 1962, Geology and groundwater resources of west-central Lewis County, Washington: Washington Department of Conservation Water Supply Bulletin 17, 248 p.

Wells, R.E., Engebretson, D.C., Snavely, P.D. Jr., and Coe, R.S., Cenozoic plate motions and the volcanic-tectonic evolution of Oregon and Washington, Tectonics, v. 3, p. $275-294$.

Wheeler, J.D. and Eddy-Miller, C.A., 2005, Seepage investigation on selected reaches of Fish Creek, Teton County, Wyoming, 2004: U.S. Geological Survey Scientific Investigations Report 2005-5133, 15 p. (Also available at http://pubs.usgs.gov/sir/2005/5133/.) 

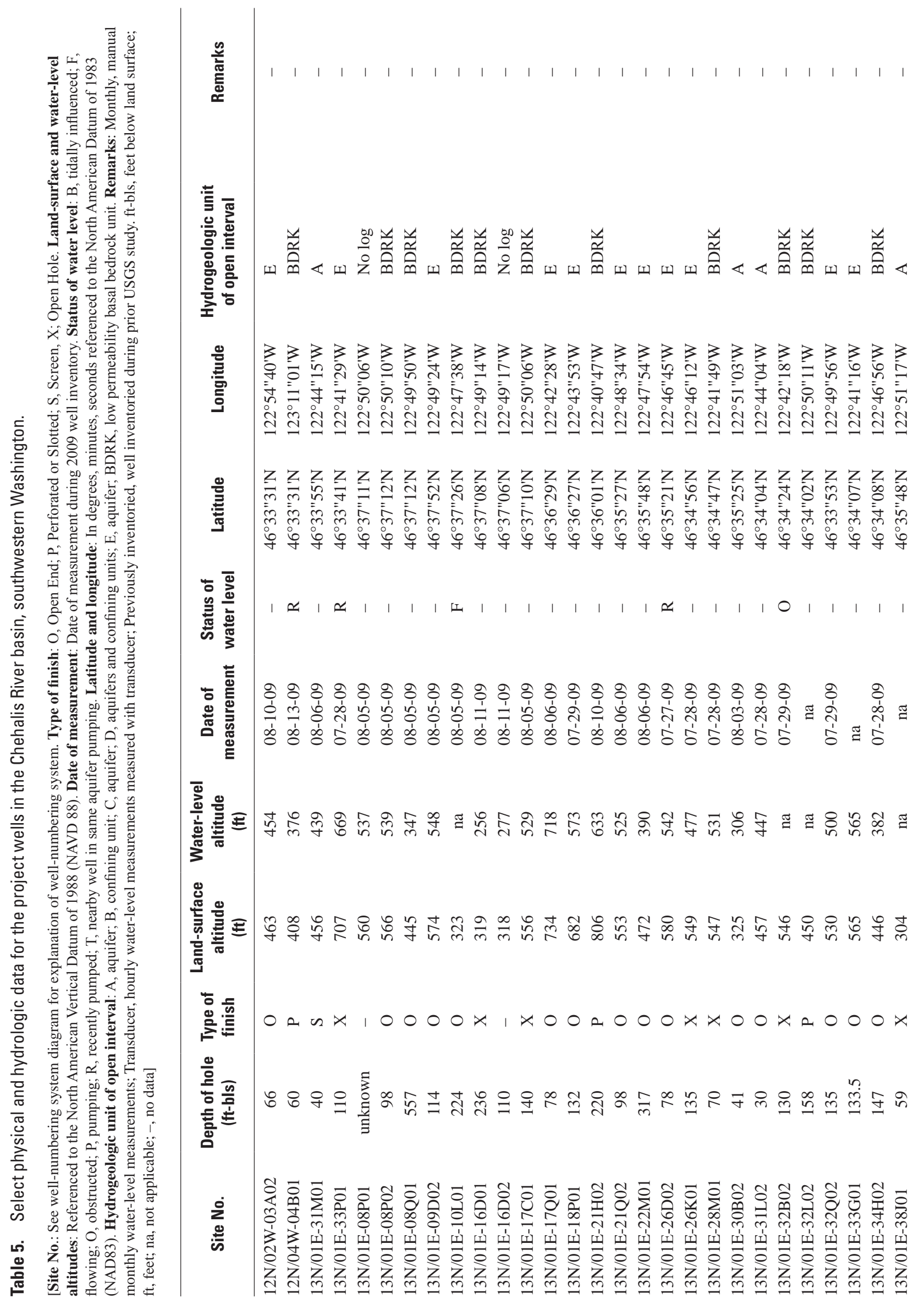


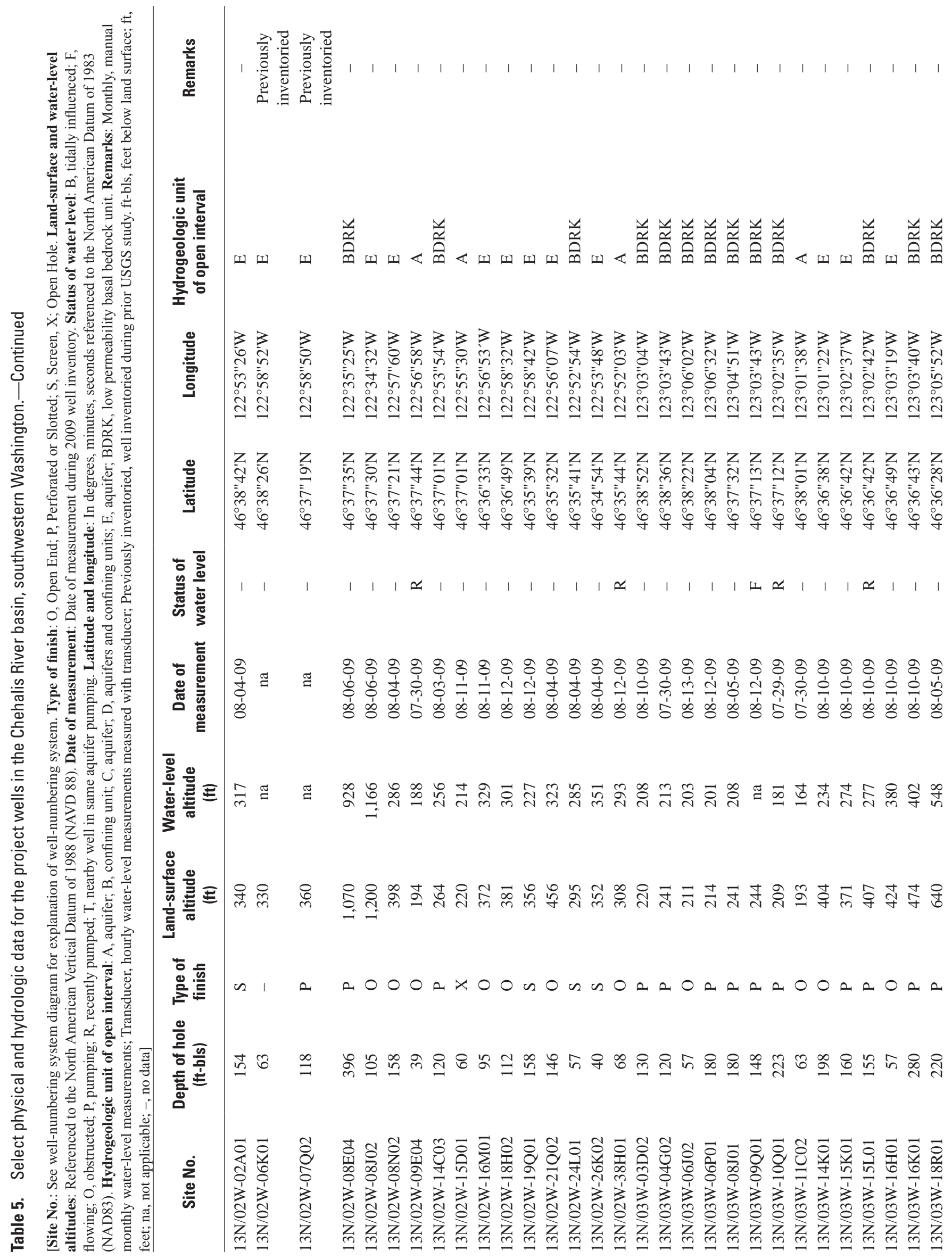




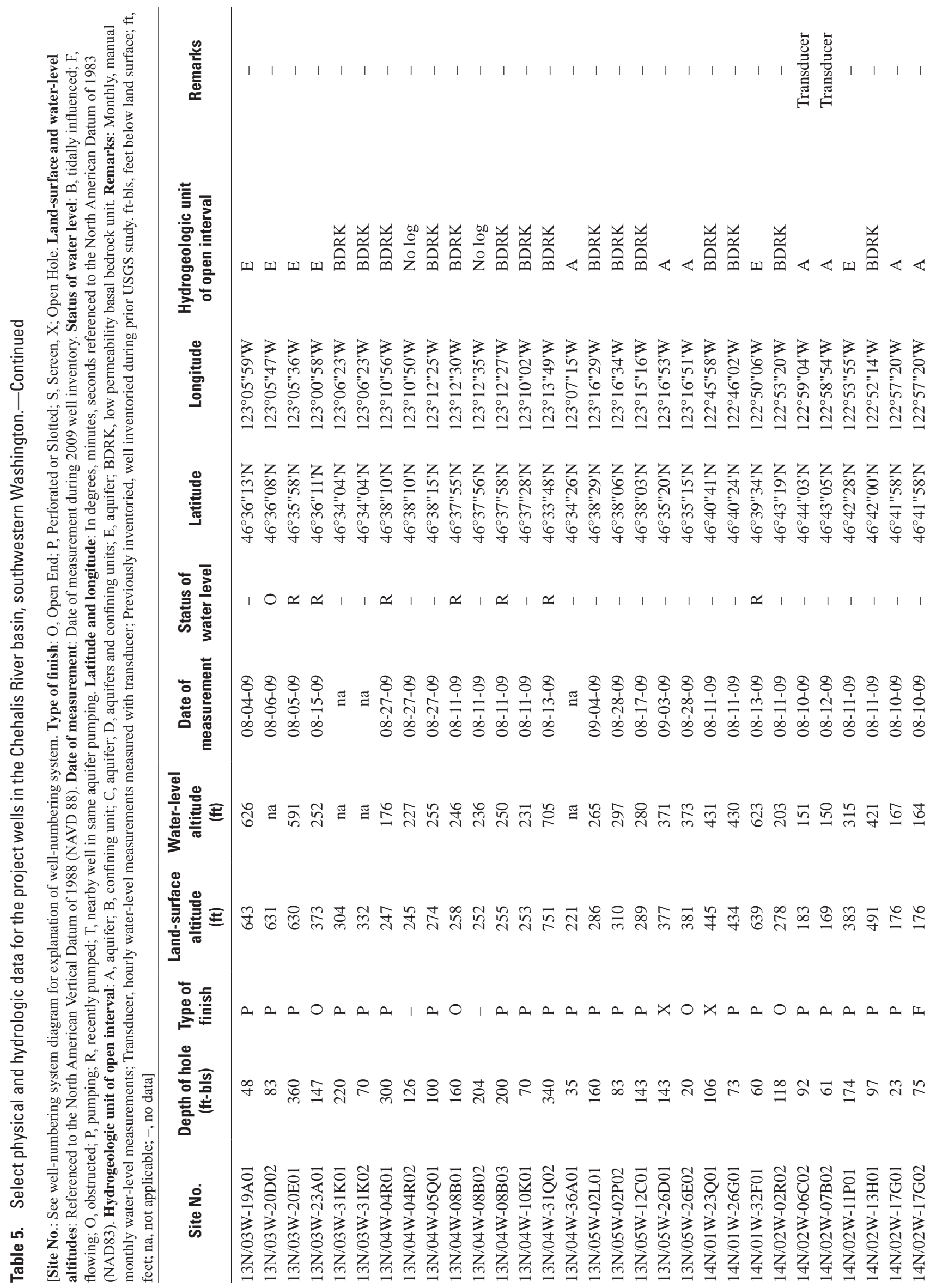




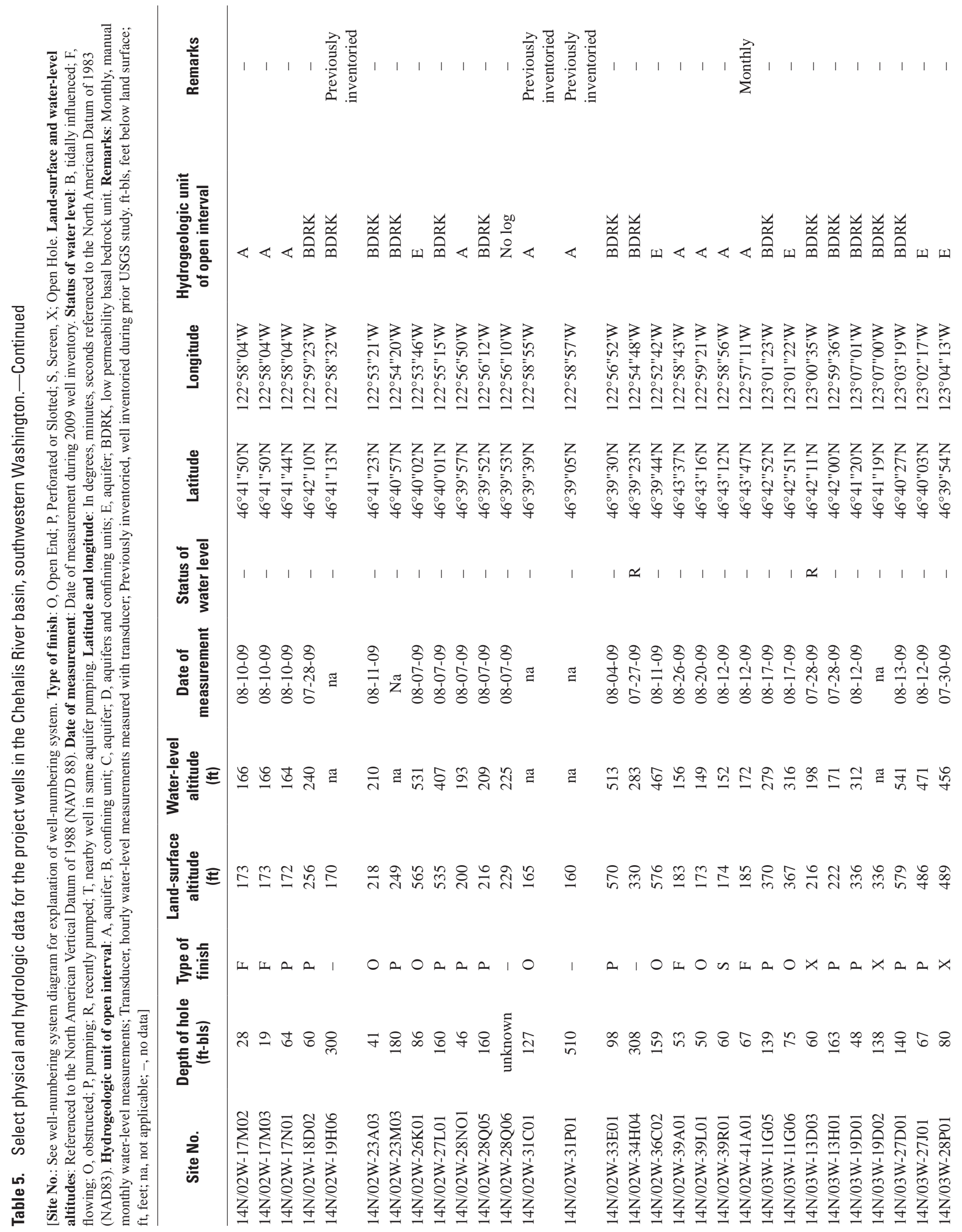


Table 5

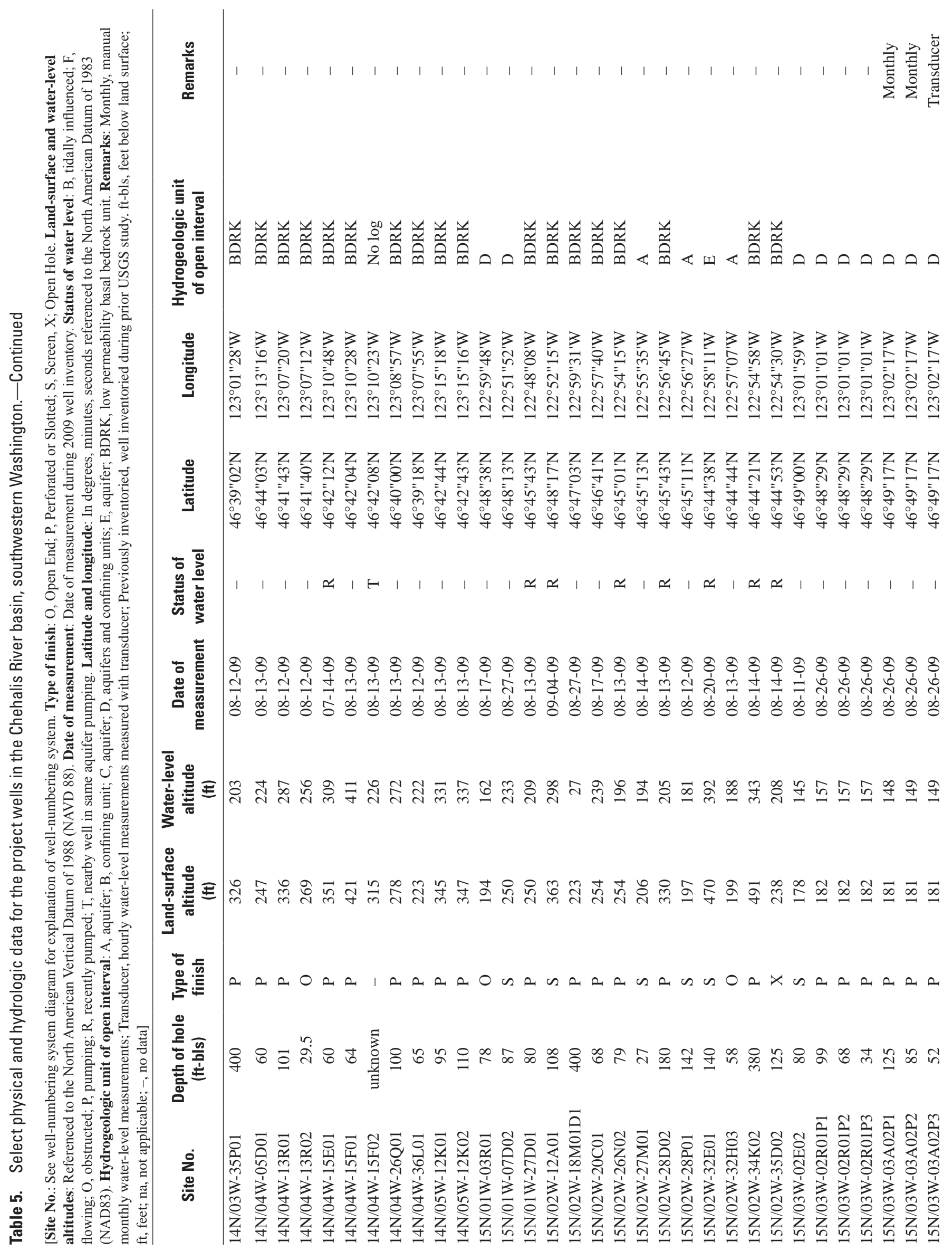




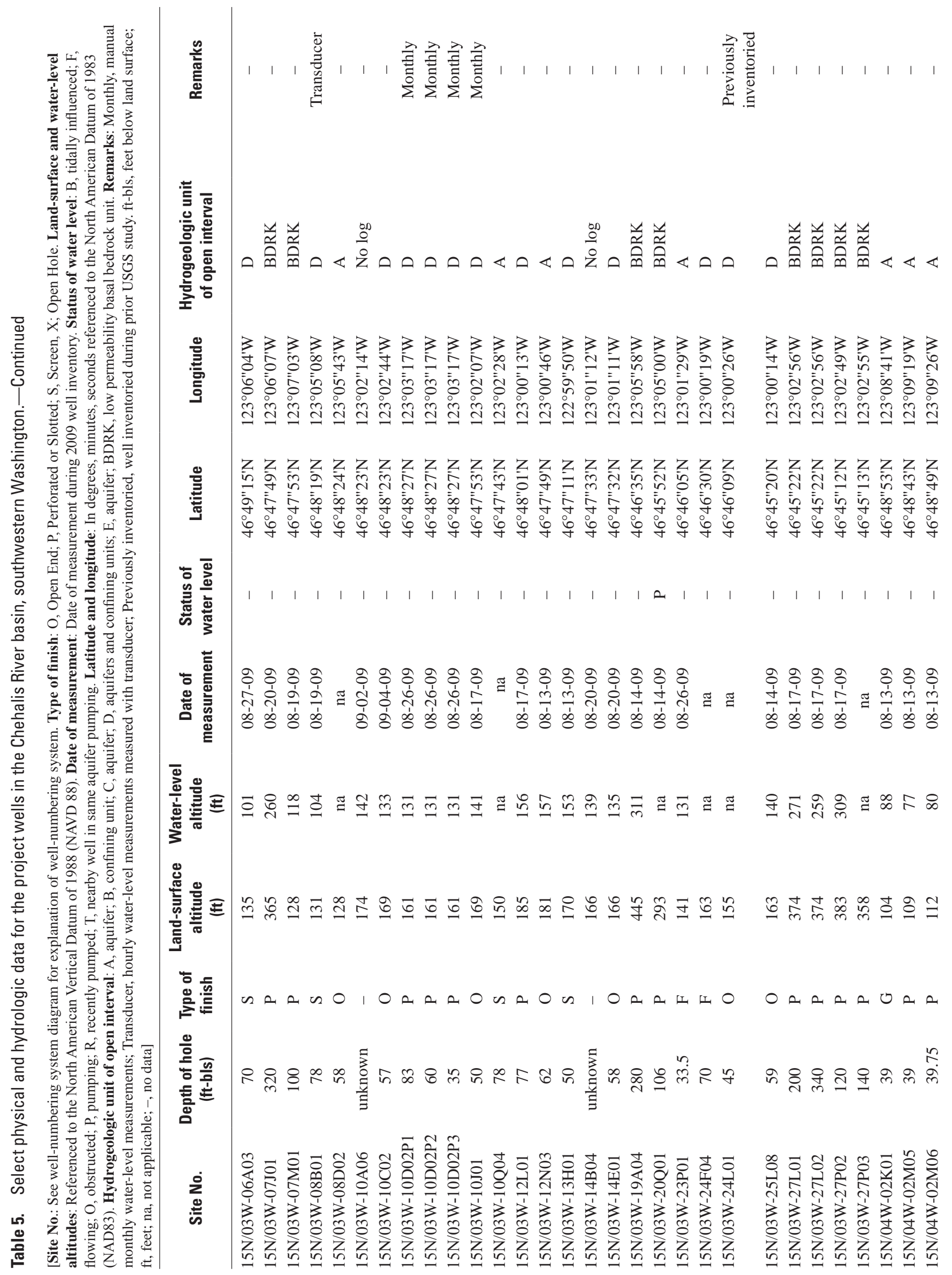




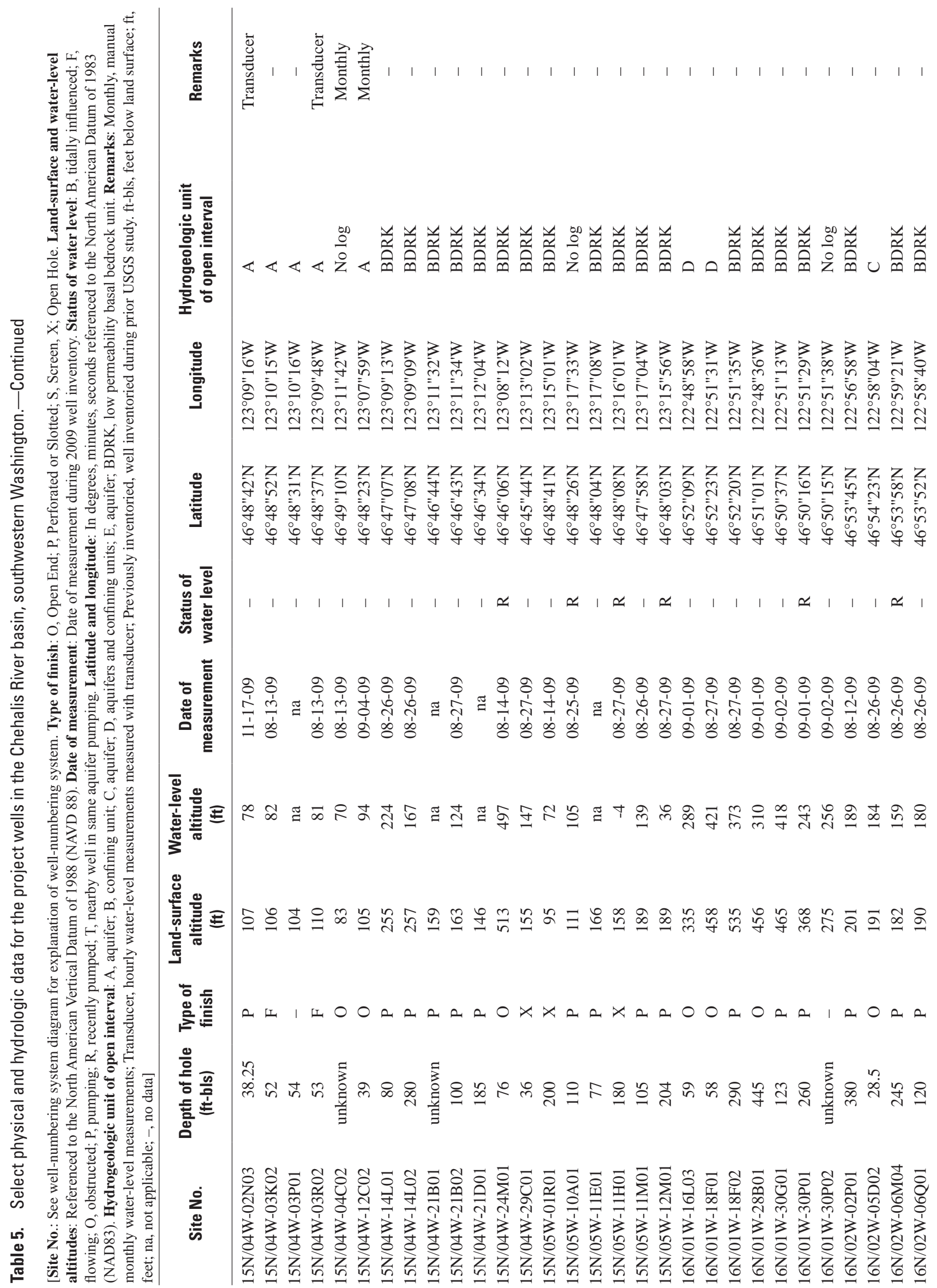




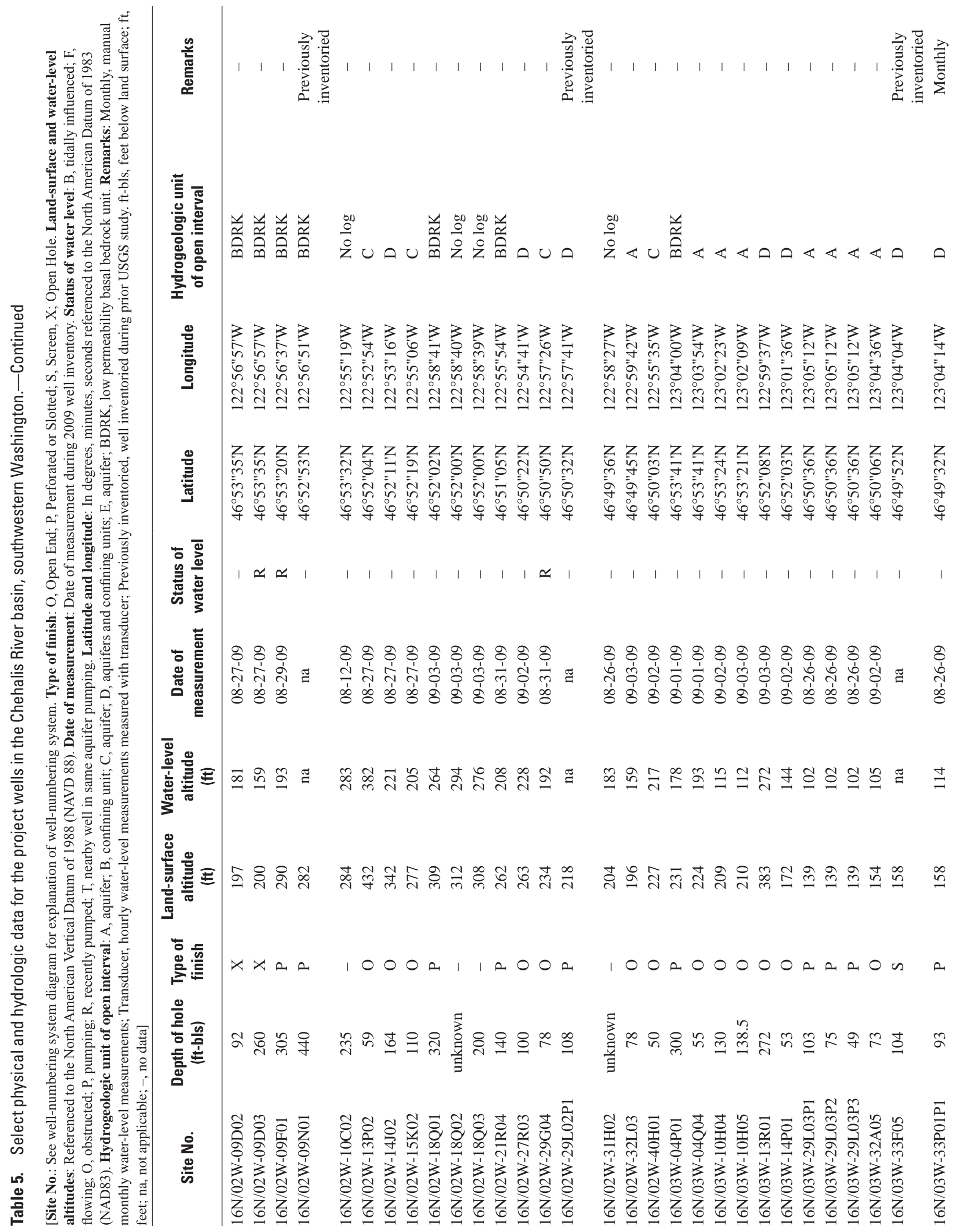




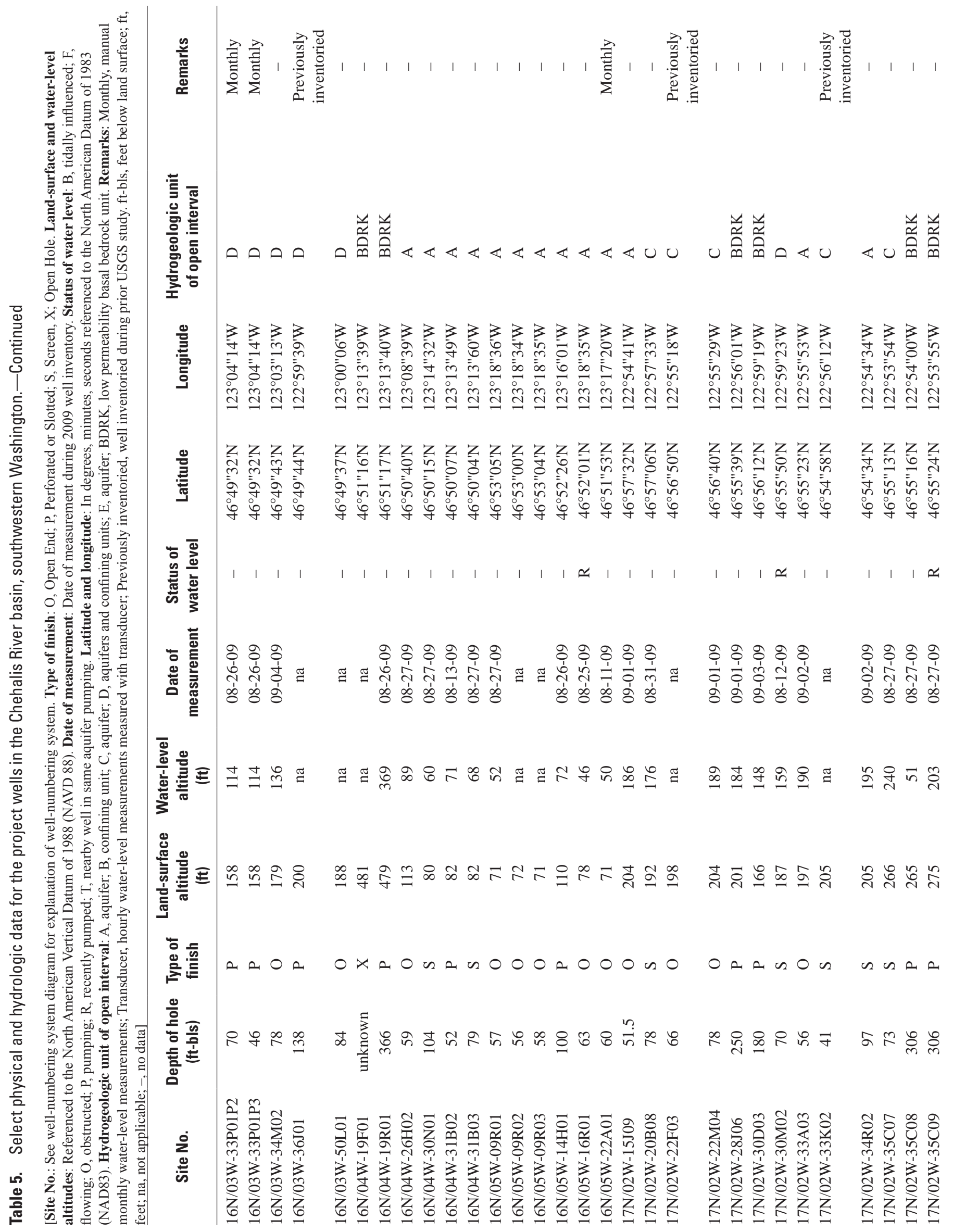




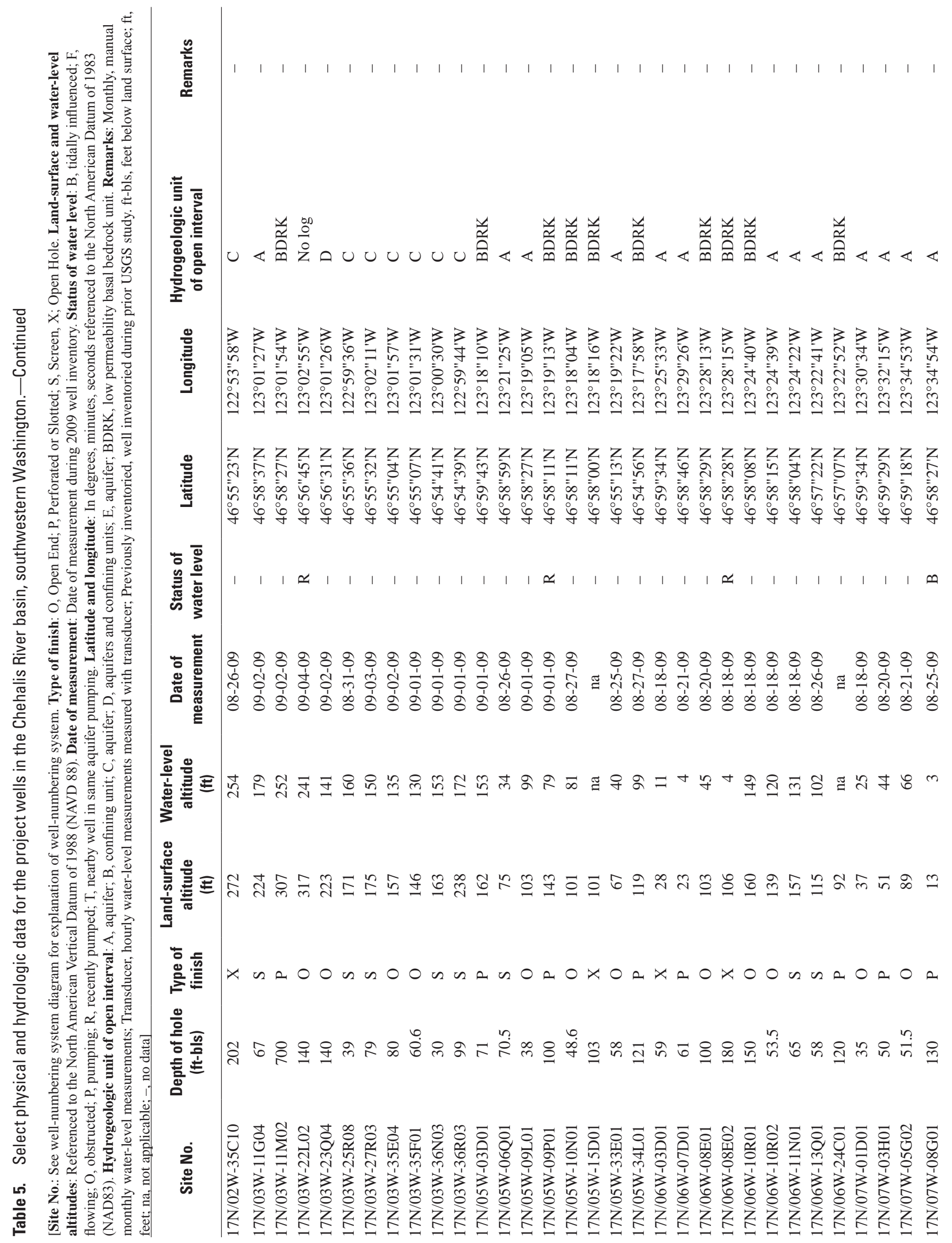




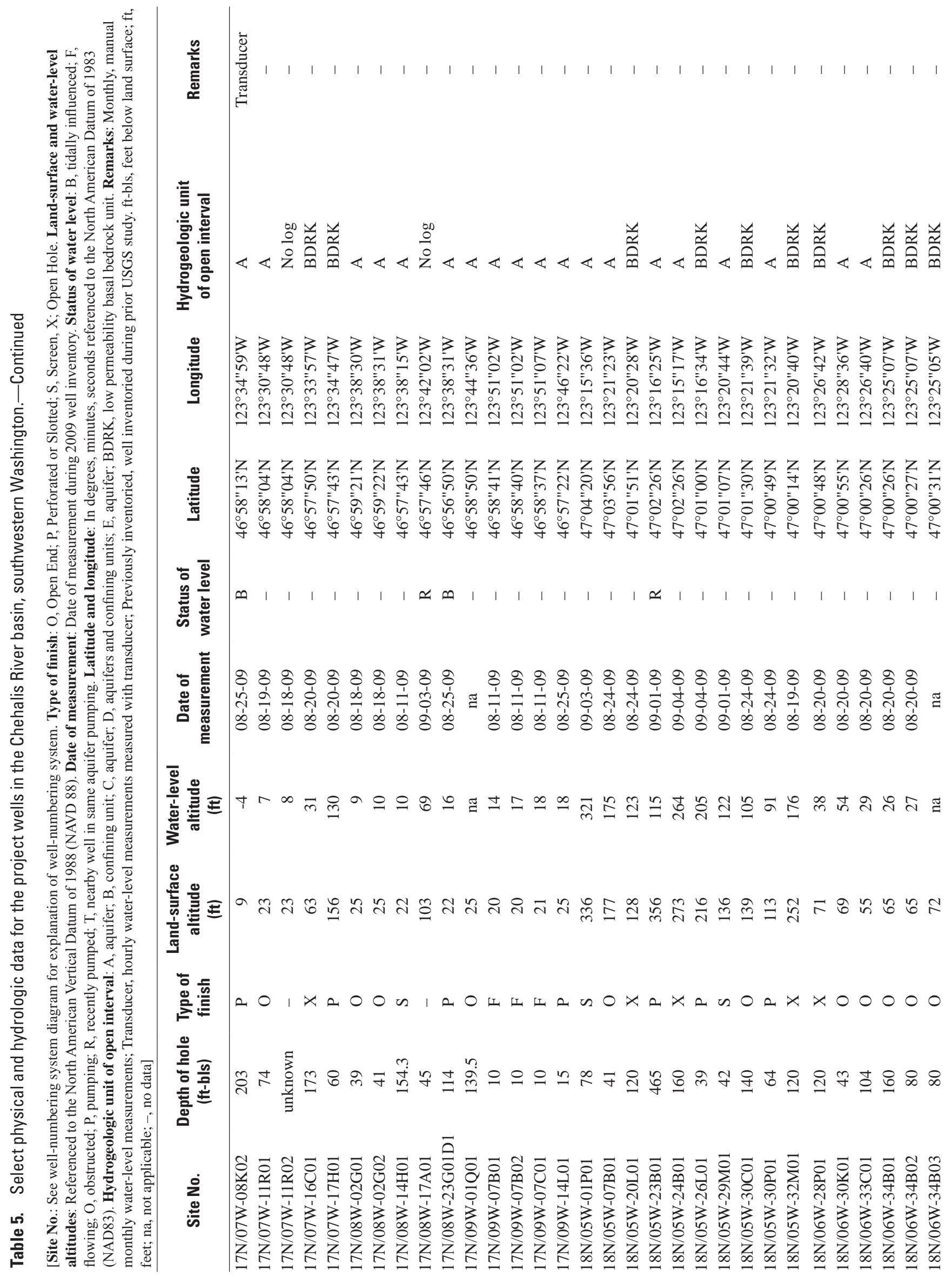




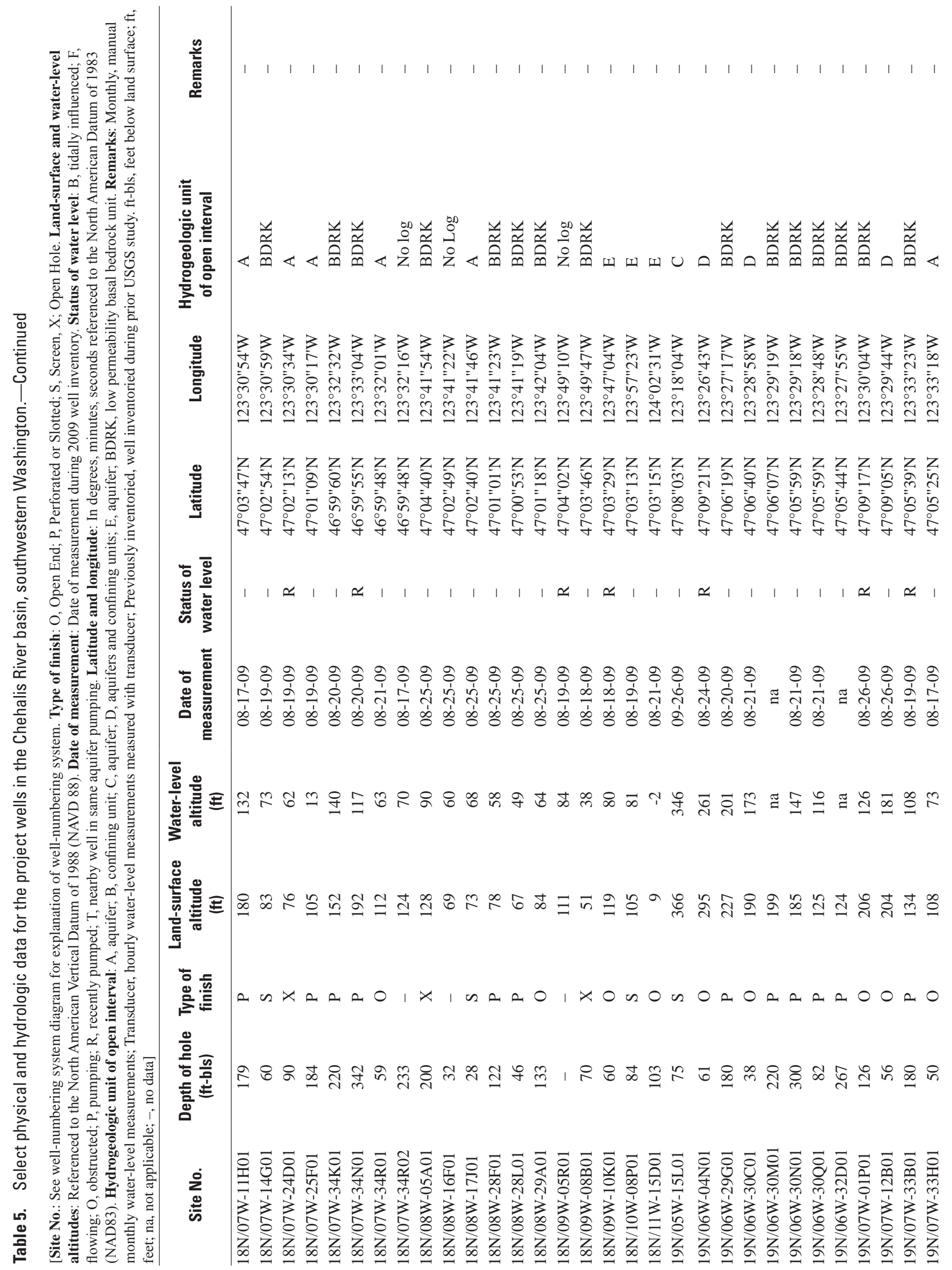




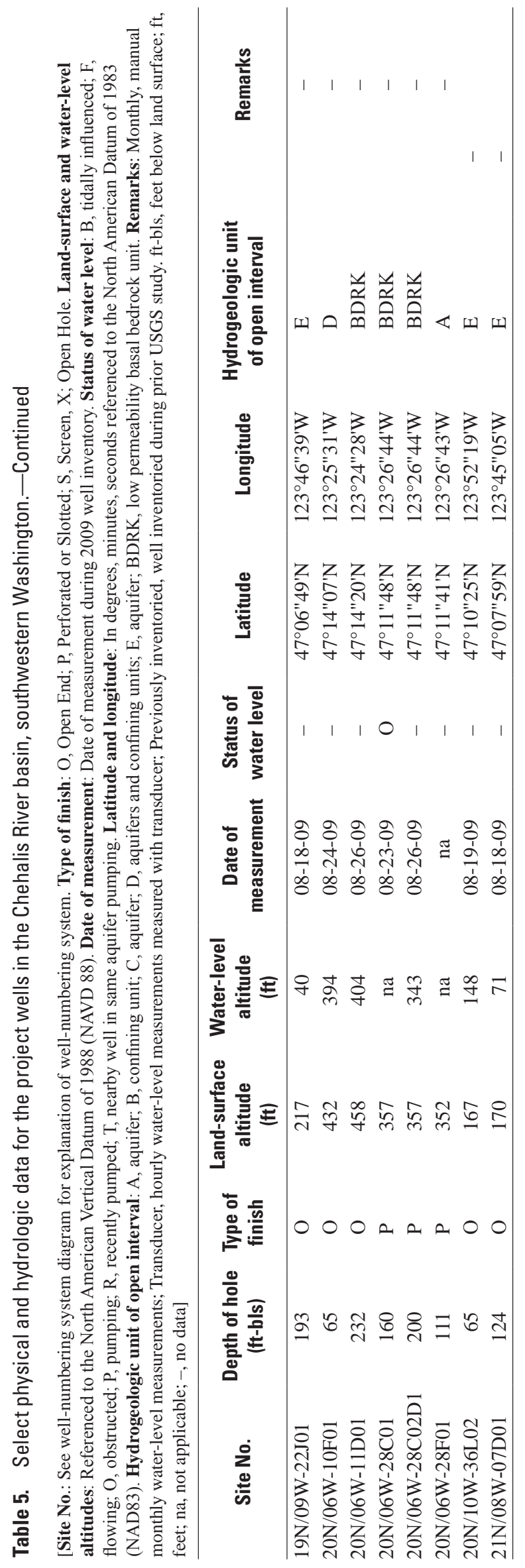


Publishing support provided by the U.S. Geological Survey

Publishing Network, Tacoma Publishing Service Center

For more information concerning the research in this report, contact the Director, Washington Water Science Center

U.S. Geological Survey

934 Broadway, Suite 300

Tacoma, Washington 98402

http://wa.water.usgs.gov 


\section{趈}

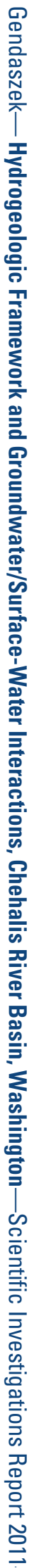

